\title{
The Three Horsemen of Riches: Plague, War, and Urbanization in Early Modern Europe
}

\author{
NICO VOIGTLÄNDER \\ UCLA Anderson School of Management and NBER \\ and \\ HANS-JOACHIM VOTH \\ ICREA CREI, Barcelona GSE, and Department of Economics, Universitat Pompeu Fabra
}

First version received November 2009; final version accepted August 2012 (Eds.)

\begin{abstract}
How did Europe escape the "Iron Law of Wages?" We construct a simple Malthusian model with two sectors and multiple steady states, and use it to explain why European per capita incomes and urbanization rates increased during the period 1350-1700. Productivity growth can only explain a small fraction of the rise in output per capita. Population dynamics — changes of the birth and death schedules-were far more important determinants of steady states. We show how a major shock to population can trigger a transition to a new steady state with higher per-capita income. The Black Death was such a shock, raising wages substantially. Because of Engel's Law, demand for urban products increased, and urban centers grew in size. European cities were unhealthy, and rising urbanization pushed up aggregate death rates. This effect was reinforced by diseases spread through war, financed by higher tax revenues. In addition, rising trade also spread diseases. In this way higher wages themselves reduced population pressure. We show in a calibration exercise that our model can account for the sustained rise in European urbanization as well as permanently higher per capita incomes in 1700, without technological change. Wars contributed importantly to the "Rise of Europe", even if they had negative short-run effects. We thus trace Europe's precocious rise to economic riches to interactions of the plague shock with the belligerent political environment and the nature of cities.
\end{abstract}

Key words: Malthus to Solow, Long-run Growth, Great Divergence, Epidemics, Demographic Regime

JEL Codes: E27, N13, N33, O14, O41

\section{INTRODUCTION}

In 1400, Europe's potential to overtake the rest of the world seemed limited. The continent was politically fragmented, torn by military conflict, and dominated by feudal elites. Literacy was low. Other regions, such as China, appeared more promising. It had a track record of useful inventions, from ocean-going ships to gunpowder and advanced clocks (Mokyn, 1990). The country was politically unified, and governed by a career bureaucracy chosen by competitive exam Pomeranz, 2000. In 14th century Europe, on the other hand, few if any of the variables that predict modern-day riches would suggest that its starting position was favourable 1 By 1700 however,

1. For a recent overview, see Bosworth and Collin 2003) and Sala-i-Martin et al. 2004. 
and long before it industrialized, Europe had pulled ahead decisively in terms of per capita income and urbanization - an early divergence preceded the "Great Divergence" that emerged with the Industrial Revolution Diamond, 1997; Broadberry and Gupta, 2006) 2

This early divergence matters in its own right. It laid the foundations for the European conquest of vast parts of the globe Diamond, 1997). It may also have contributed to the even greater differences in per capita incomes that followed. In many unified growth models, an initial rise of per capita income is crucial for the transition to self-sustaining growth Galor and Weil, 2000; Hansen and Prescott, 2002). Also, there is growing evidence that a country's development in the more distant past is a powerful predictor of its current income position Comin et al. 2010 . Voigtländer and Voth 2006) develop a model in which greater industrialization probabilities are the direct consequence of higher starting incomes. If we are to understand why Europe achieved the transition from "Malthus to Solow" before other regions of the world, explaining the initial divergence of incomes is crucial.

In a Malthusian economy, the "Iron Law of Wages" should hold-incomes can change temporarily, until population catches up 3 Nonetheless, many European countries saw marked increases in per capita output. Maddison 2007) estimates that Western European per capita incomes on average grew by $30 \%$ between 1500 and 1700. Urbanization rates-often used as a better indicator of per capita output—also rose rapidly 4 In the most successful economies, both incomes and urbanization rates more than doubled. How could output per capita rise substantially in a Malthusian economy?

We develop a simple two-sector model where shocks to population size can lead to permanently higher incomes. Before describing our mechanism, we briefly review the standard Malthusian model in the left panel of Figure 1 Death rates are downward sloping in income, and birth rates are either flat or upward sloping. This generates a unique steady state $(C)$ that pins down wages and population size. Decreasing marginal returns to labour set in quickly as population grows because fixed land is an important factor of production. A decline in population can raise wages, moving the economy to the right of $C$. However, the increase in output per capita is only temporary. Birth rates now exceed death rates and population grows, which in turn will depress wages- the "Iron Law of Wages" holds 5 We modify the standard Malthusian model to explain how early modern European incomes could rise permanently. We do so by introducing a particular mortality regime. In the right-hand panel of Figure 1 we show a Malthusian model where death rates increase with income over some range. We refer to the upward-sloping mortality schedule as the "Horsemen effect". Steady state $E_{0}$ combines low income per capita with low mortality, while steady state $E_{H}$ is characterized by higher wages and higher mortality. Point $E_{U}$ is an unstable steady state. Suppose that the economy starts out in $E_{0}$. A major positive shock to wages (beyond $E_{U}$ ) will trigger a transition to the higher-income steady state.

The Black Death was a shock that raised incomes significantly. It killed between one-third and half of the European population in 1348-50. This raised land-labour ratios, and led to markedly higher wages. In Figure 1 such a shock moves the economy beyond point $E_{U}$. From there,

2. Western European urbanization rates were more than double of those in China Maddison, 2001; Broadberry and Gupta 2006). We discuss the evidence at greater length in Section 2

3. In the words of H.G. Wells, earlier generations should have always "spent the great gifts of science as rapidly as it got them in a mere insensate multiplication of the common life" Wells 1905. This is the intuition behind Ashraf and Galor 2011), who test for long-term stagnation of incomes despite variation in soil fertility and agricultural technology.

4. Maddison considers urbanization as one of many factors influencing his estimates of GDP. The latest installments of his figures contain numerous, country-specific adjustments based on detailed research by other scholars.

5. Technological innovation has an affect akin to a drop in population: wages rise temporarily but eventually converge back to the unique steady state. 

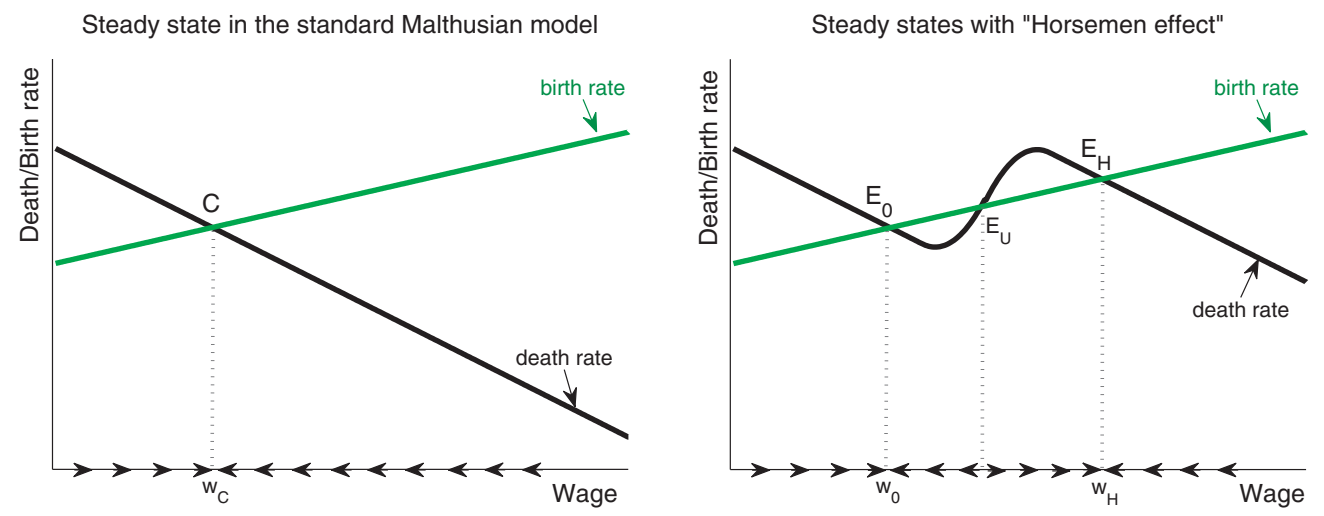

FIGURE 1

Steady states in the standard Malthusian model and with "Horsemen effect"

it converges to $E_{H}$. This is equivalent to a "ratchet effect": Wage gains after the Black Death became permanent 6

The crucial feature to obtain multiple steady states in Figure 1 is an upward-sloping part of the death schedule. This reflects the historical realities of early modern Europe 7 According to Malthus 1826), factors reducing population pressure include "vicious customs with respect to women, great cities, unwholesome manufactures, luxury, pestilence, and war." We focus on three-great cities, pestilence, and war. All of them increased in importance after the plague because of higher per capita incomes. High wages were partly spent on manufactured goods, mainly produced in urban areas. Cities in early modern Europe were death-traps, with mortality far exceeding fertility rates. Thus, new demand for manufactures pushed up aggregate death rates. War and trade reinforced this effect. Between 1500 and 1800, the continent's great powers were fighting each other on average for nine years out of every ten Tilly, 1992). This was deadly mainly because armies on the march often spread epidemics. Wars could be financed more easily when per capita incomes were high. The difference between income and subsistence increased, leaving more surplus that could be spent on war. In effect, war was a "luxury good" for princes. In addition, trade grew as people became richer, and it also spread germs 8 In this way, the initial rise in wages after the Black Death was made permanent by the 'Horsemen effect,' pushing up mortality rates and producing higher per capita incomes. Thus, Europe experienced a simultaneous rise in war frequency, in deadly disease outbreaks, and in urbanization. The Horsemen of the Apocalypse effectively acted as "Horsemen of Riches"

6. A large positive shock to technology could theoretically also cause this transition. However, pre-modern rates of productivity growth are much too low to trigger convergence to the high-income steady state.

7. The theoretical and historical conditions under which the "Horsemen effect" led to multiple steady states are discussed in detail in Section 2

8. Numerous studies have focused on the interaction between domestic armed conflict and income. Many find that civil wars decline in frequency after positive growth shocks Collier and Hoefflen, 1998, 2004; Miguel et al., 2004. In contrast, Grossman 1991) has argued that higher incomes should promote wars ("rapacity" effect), as there is more to fight over. Martin et al. 2008) find that more multilateral trade can lead to more war.

9. This is the opposite of the negative effect of wars, civil wars, disease, and epidemics on income levels found in many economies today (cf. Murdoch and Sandlen, 2002; Hoeffler and Reynal-Quero], 2003). The main reason for this difference is that human capital is crucial for development today, while it was not in pre-modern times, when decreasing returns to (unskilled) labour in agriculture dominated the production pattern. 
To our knowledge, this study is the first to investigate quantitatively the factors behind Europe's early rise to riches. We do so in a comparative perspective. The great 14 th-century plague also affected China, as well as other parts of the world McNeil1, 1977). Why did it not have the same effects there? We argue that the Chinese demographic regime did not feature multiple steady states. Similar shocks did not lead to permanently higher death rates for two reasons. Chinese cities were far healthier than European ones. Also, political fragmentation in Europe ensured continuous warfare. China, on the other hand, was politically unified, except for brief spells of turmoil. There was no link between p.c. income and the frequency of armed conflict. In Western Europe, a unique set of geographical and political starting conditions interacted with the plague shock to make higher wages sustainable; where these starting conditions were absent, transitions to higher incomes were much less likely. China can thus be represented by the standard Malthusian model in the left panel of Figure 1 with a unique low-income steady state.

We are not the first to argue that higher death rates can raise p.c. income. Young 2005) concludes that HIV in Africa has a silver lining because it increases the scarcity of labour, boosting the consumption of survivors 10 Clark 2007) highlights the benign effect of higher death rates on p.c. income in the Malthusian period. Lagerlöf 2003) also examines the interplay of growth and epidemics. He concludes that a decline in the severity of epidemics can foster growth if they stimulate human capital acquisition 11 Brainerd and Sieglen 2003) study the outbreak of "Spanish flu" in the USA, and conclude that the states worst-hit in 1918 grew markedly faster subsequently. Compared to these papers, we make three contributions. First, we use the Malthusian model to explain permanently higher wages, not stagnation at a low level. Second, we are the first to demonstrate how specific European characteristics interacted with a large mortality shock to drive up incomes over the long run, leading to the "First Divergence". Third, we calibrate our model to show that it can account for a large part of the "Rise of Europe" in the early modern period.

Other related literature includes the unified growth models of Galor and Weil 2000) and Galor and Moav 2002). In both, before fertility limitation sets in and growth becomes rapid, a state variable gradually evolves over time during the Malthusian regime, making the final escape from stagnation more and more likely. In Galor and Weil (2000), Jones (2001), and Kremen 1993), the rise in population produces more ideas; in Galor and Moav (2002), the quality of the population is the key factor 12 Cervellati and Sunde 2005) argue that the mortality decline from the 19th century onwards was an important element in the transition to self-sustaining growth, by increasing human capital formation. Hazan 2009) raises doubts about the underlying Ben-Porath mechanism. Hansen and Prescot 2002) assume that productivity in the manufacturing sector increases exogenously, until part of the workforce switches out of agriculture; Desmet and Parente 2009) conclude that market size was key. Strulik and Weisdor 2008) argue that in a Malthusian regime with a strong preventive check, productivity growth in industry raised the relative cost of having children 13

10. In contrast, Lorentzen et al. 2008) argue that higher mortality in Africa-including from AIDS-reduces incentives to accumulate capital, and thus reduces growth.

11. In a similar vein, Kalemli-Ozcan 2002 argues that declines in mortality were growth-enhancing. Lagerlö 2010) studies income in a Hansen-Prescott type two-sector long-run growth model with war-induced deaths. He shows that the transition to a Solow economy can explain the decline in warfare in the 19th century, i.e. after the period that we focus on.

12. Clark 2007) finds some evidence in favour of the Galor-Moav hypothesis, with the rich having more surviving offspring.

13. Sharp et al. 2012) show how falling prices of manufactured goods can lead to fertility decline and thus higher wages in steady state. Vollrath 2011) argues that more labour-intensive agriculture is associated with higher population density and lower per-capita incomes, which can contribute to the First Divergence between Europe and China. 
Our model emphasizes changes in death rates as a key determinant of output per head. We also show that technological change can only explain a small fraction of the rising p.c. income in early modern Europe. One of the key advantages of our framework is that it can be applied to the cross-section of growth outcomes. In contrast, the majority of existing unified growth papers implicitly uses the world as their unit of observation. We deliberately limit our attention to the early modern divergence between Europe and China. While models such as Kremer 1993) and Hansen and Prescott 2002) try to explain the entire transition to self-sustaining growth, we simply examine the initial divergence of incomes, long before technological change became rapid 14

Our article adds to the literature on the origins of European exceptionalism. Diamond 1997) argued that geographical factors combined with grain and animal endowments in pre-historic times strongly influenced which continent did best after 1500. Mokyn 1990) emphasized Europe's superior record of invention after 1300. Jones (1981) sees a relatively liberal political environment as key. In the same vein, Acemoglu et al. 2005) argue that in Northwestern Europe, Atlantic trade helped to constrain monarchical powers, accelerating growth after 1500 15 Our article emphasizes a combination of geographical and political factors, as well as the peculiar conditions of urban life. These starting conditions interact with the exogenous shock of the plague in a unique way that could not have occurred in a consolidated imperial state. The large number of European states ensured that higher incomes translated into more wars. Combined with the filth and overcrowding of European cities, this turned one-off increases in wages into permanently higher incomes.

We proceed as follows. The next section provides a detailed discussion of the historical context. Section 3 introduces a simple two-sector model that highlights the main mechanism. In Section 4 we calibrate our model and show that it captures the salient features of the "First Divergence". The final section summarizes our findings.

\section{HISTORICAL CONTEXT AND BACKGROUND}

In this section, we discuss historical evidence for the key elements of the framework presented in Figure 1 A large increase in per capita income can move the economy over the threshold $E_{U}$ so that it converges to $E_{H}$-the high-income steady state. For this mechanism, an upward-sloping part of the death schedule is crucial. In the following, we first summarize the impact of the ultimate cause of Europe's riches in our model—the Black Death's effect on per capita income. Next, we describe the three factors that cause death rates to rise with income-urbanization, wars, and trade. In this context, Engel's Law is important because it ensures that manufacturing-and thus urbanization-grows rapidly with income. Finally, we summarize the evidence for the final outcome, Europe's precocious rise to riches before 1800 (the "First Divergence").

\subsection{The plague}

The plague arrived in Europe from the Crimea in 1347. Tartar troops besieging the Genoese trading outpost of Caffa passed it on to the defenders. The disease spread with the fleeing Genoese, via Constantinople and Sicily to mainland Italy, and finally to the rest of Europe. By December 1350, it had reached the North of England and the Baltic McNeill, 1977). Mortality rates amongst

14. Galor and Wei 2000) distinguish between a Malthusian, a Post-Malthusian, and a Solow period of growth. We argue in effect that a period of Malthusian dynamism superseded aeons of Malthusian stagnation, and that doing so prepared the ground for the Post-Malthusian world.

15. Their contribution reverses the conclusion of an earlier literature, which had questioned the discoveries' importance for the "Rise of Europe" Engerman, 1972; O'Brien, 1982. 

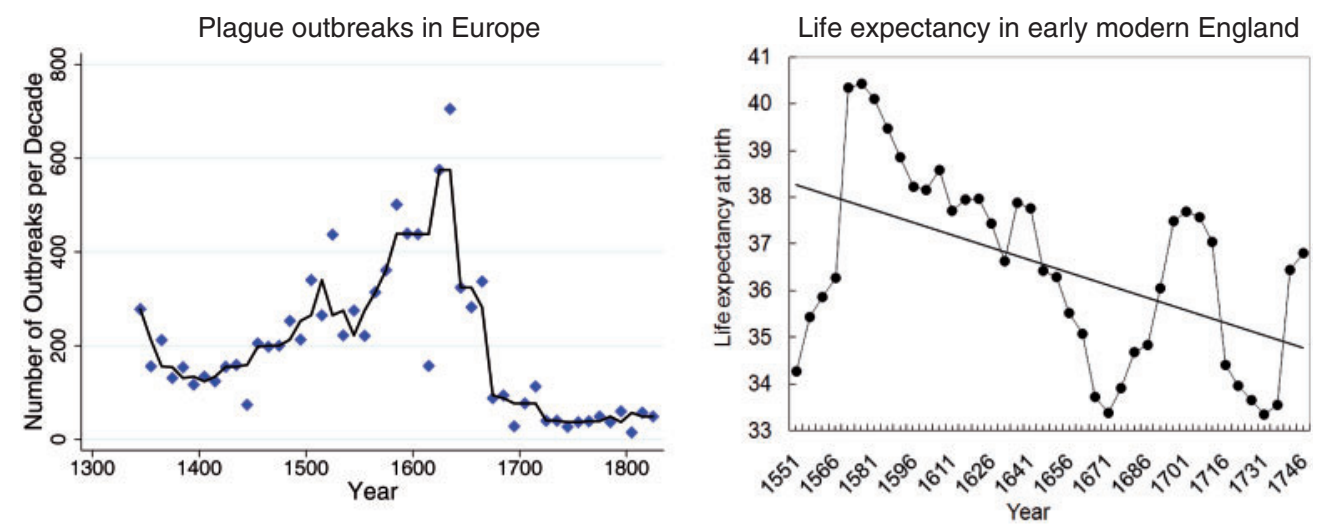

FIGURE 2

Plague outbreaks in Europe and life expectancy in early modern England. Sources: Left panel:Biraben 1975. Data points represent the number of outbreaks over 10-year periods. The solid line is the median of each data point and the two adjacent ones. Right panel:Wrigley and Schofield 1981); 20-year moving average

those infected varied from $30 \%$ to $95 \%$. Both cities and the countryside suffered. Only a handful of areas in the Low Countries, in Southwest France and in Eastern Europe were spared the Black Death 16 Aggregate population losses amounted to 15-25 mio., out of a population of roughly 40 mio. The "Great Plague" was followed by a wave of smaller outbreaks. As shown in the left panel of Figure 2 the number of plague epidemics more than quadrupled between the 14th and the 17 th century, to a peak of 705 in 1630-40. The frequency of outbreaks only declined from the late 17 th century onwards.

Plague was not the only epidemic to strike Europe. There were also outbreaks of smallpox, cholera, and typhus. Combined with other factors, these epidemics contributed to a downward trend in life expectancy in the early modern period. The right panel of Figure 2 illustrates this for the case of England.

The plague matters in our model because it triggered a large increase in per capita income. The gains after 1348 were not fully reversed thereafter. During the "golden age of labour" Postan, 1972) in England after 1350, wages approximately doubled Clark, 2005; Phelps-Brown and Hopkins, 1981). Afterwards, the evidence suggests a decline. Clark 2005) shows that wages fell back from their peak somewhat, but except for crisis years around the English Civil War, they remained above their pre-plague level 17 The existing wage series therefore reinforce the optimistic GDP figures provided by Maddison 2007), who estimates that European p.c. income grew by one-third between 1500 and 170018

16. Approximately half of the English clergy died, and in Florence and Venice, death rates have been estimated as high as 60-75\% Zieglen, 1969, Benedictow, 2004.

17. The older Phelps-Brown and Hopkins series suggests a stronger decline after 1450. What matters for the predictions of the Malthusian model is per capita output, not wages as such. Accordingly, Broadberry et al. 2011. show that British output per head increased by approximately one-third in 1350 and stabilized at this high level until the onset of the Industrial Revolution in the 18th century.

18. Not all of Europe did equally well. Allen 2001) found that real wage gains for craftsmen after the Black Death were only maintained in Northwestern Europe. In Southern Europe-especially Italy, but also Spain-stagnation and decline after 1500 are more noticeable. The North-West overtook Southern Europe in terms of urbanization rates and output Acemoglu et al. 2005. Nonetheless, every European country with the exception of Italy had higher per capita 


\subsection{Elements of the "Horsemen effect"}

In Figure 1 for the existence of multiple steady states it is crucial that there is an upward sloping part of the death schedule-mortality rates have to increase with incomes over some part of the income range. Europe's peculiar mortality pattern was driven by the perils of urban life, and diseases spread by trade and war. We briefly discuss how each contributed to higher mortality.

2.2.1. City mortality and manufacturing. European cities were deadly. Early modern English urban mortality rates were 1.8 times higher than in the countryside Clark and Cummins, 2009). A comprehensive survey of rural-urban mortality differences shows that in Europe before 1800, life expectancy was typically 50\% higher in the countryside than in cities Woods, 2003). In London, 1580-1799, it fluctuated between 27 and 28 years (Landers, 1993), and provincial towns like York had similar rates of infant mortality Galley, 1998). At the same time, in England as a whole, life expectancy was $35-40$ years 19

Why did Europeans move to unhealthy cities? First, those who moved were not necessarily the ones who died-infant mortality was a major contributor to the urban-rural mortality differential. Second, cities offered other amenities - a wider range of available goods, and freedom from servitude for those who stayed long enough. Third, urban wages were generally higher than rural ones. The wage differential reflected the concentration of manufacturing activities in cities. This was enforced by guilds watching jealously over their monopoly of producing certain goods. While some manufacturing activity gradually moved to rural locations from the 16th and 17th century onwards, the vast majority of non-agricultural goods in early modern Europe was produced in cities and towns Coleman, 1983.

No similar urban mortality penalty existed in China. Chinese infant mortality rates were lower in cities than in rural areas, and life expectancy was similar or higher 20 Members of Beijing's elite in the 18th century experienced infant mortality rates that were less than half the rates in France or England 21 On average, during the period 1644-1899, men born in Beijing had a life expectancy at birth of 31.8 years. In rural Anhui, the corresponding figure was 31 Lee and Feng, 1999). Other evidence lends indirect support. For example, life expectancy in Beijing in the 1920s and 1930s was higher than in the countryside 22 Principal reasons probably include the transfer of "night soil" (i.e. human excrement) out of the city and onto the surrounding fields for fertilization, relatively high standards of personal hygiene, and a diet rich in vegetarian food. Since the proximity of animals is a major cause of disease, all these factors combined to reduce the urban mortality burden in the Far East.

Relatively high urban mortality in Europe also reflected the way in which cities were built. Because warfare was common, European cities were typically surrounded by fortifications. These limited city growth De Vries, 1976). In China, the defensive function of city walls declined

GDP in 1700 than in 1500. Maddison assumes that subsistence is equivalent to approximately \$400 US-Geary Khamy dollars. Even relatively poor countries like Spain and Portugal had per capita incomes more than twice as high in 1700 .

19. The only exceptions are two quinquennia when it dropped lower Wrigley et al. 1997). In York, there is not enough data to derive life expectancy. However, infant mortality - a prime determinant of life expectancy-was in the same range in provincial towns and London.

20. The available mortality estimates have been derived from the family trees of clans Tsui-Jung, 1990, using data from the 15 th to the 19 th century.

21. Woods 2003). The average infant mortality rate in the English cities listed before 1800 is 262; for Beijing, it is 104 .

22. Some recent evidence Hayami, 2001) on adult mortality questions if Far Eastern cities were indeed healthier than the countryside, as some scholars have argued Hanley, 1997; Macfarlane, 1997). There is no discussion about the cities being markedly less healthy. 
after the country's unification; houses and markets spread outside the city walls. This reduced overcrowding and kept mortality rates relatively low.

2.2.2. Engel's law. Consumers grown rich(er) after the Black Death spent relatively less on food, and more on manufacturing goods: consumption patterns in medieval England suggest that Engel's Law held. Dyen 1988) documents how the share of income spent on food declined with social status. Peasants spent a high proportion; clerical households earning $£ 20$, half of their income; earls earning thousands of pounds sterling, less than a quarter. Over time, following the Black Death, the pattern is also clear. Spending by peasants on dwellings, clothing, cooking utensils, ceramics, and furniture all increased (as reflected in probate inventories) 23 For England in the early modern period, the income elasticity of food expenditure was 0.76 (Horrell, 1996). This is similar to estimates for present-day India (0.7, as derived in Subramanian and Deaton, 1996). In combination, there is ample evidence-both in the cross-section, and over time-that Engel's law applied after 1350 .

2.2.3. The impact of war. War matters for our model because it pushed up aggregate death rates, raising land-labour ratios. We also argue that it had relatively limited negative direct effects on output, acting more as the early modern equivalent of a "neutron bomb".

Battlefield casualties were generally low, compared to aggregate death rates 24 Armies were generally too small for military deaths to influence aggregate mortality rates substantially 25 Instead, early modern armies killed by exposing isolated communities to new germs. In one famous example, a single army of 6000 men, dispatched from La Rochelle (France) to deal with the Mantuan Succession in Northern Italy, spread plague that may have killed up to one million people Landers, 2003). As late as the Napoleonic wars, typhus, smallpox, and other diseases spread by armies marauding across Europe proved far deadlier than guns and swords.

Aggregate civilian population losses in wartime could be heavy. The Holy Roman Empire lost 5-6 mio. out of 15 mio. inhabitants during the Thirty Years War; 20\% of the French population died in the late 16th-century as a result of civil war. The figures for early 17 th-century Germany and 16th-century France imply that aggregate mortality rates rose by $50-100 \%$, and that these rates were sustained for decades. For the early and mid-nineteenth century, we have additional data on the indirect, country-wide rise in mortality from warfare. During the Swedish-Russian war of 1808-09, mortality rates in all of Sweden doubled, almost exclusively through disease. In isolated islands, the presence of Russian troops—without any fighting — led to a tripling of death rates Landers, 2003).

Warfare became increasingly expensive during the early modern period Tilly, 1992; Landers, 2003). The "military revolution" brought professional, drilled troops, Italian-style fortifications, ships, muskets, and cannons. To make war, princes had to draw on liquid funds. After the plague, incomes per capita were higher; there was more surplus above subsistence that could

23. Dyer 1988) also notes that the quality of goods improved: "Pewter tableware and metal ewers replaced some wood and pottery vessels for more substantial peasants, and ceramic cisterns supplanted wooden casks. Potters began to supply cups, which had all previously been made of wood... The dice, cards, chessmen, footballs, musical instruments and "nine-men's morris' boards show that resources could be spared..."

24. Data on deaths caused by military operations in the early modern period are sketchy. Landers 2003) offers an overview of battlefield deaths. Lindegren 2000) finds that military deaths only raised Sweden's aggregate death rates by 2-3/1000 in most decades between 1620 and 1719, a rise of no more than 5\%. Castilian military deaths were 1.3/1000, equivalent to $10 \%$ of adult male deaths but no more than $3-4 \%$ of overall deaths.

25. Since infant mortality was high, by the time men could join the army, many male children had died already. This makes it less likely for military deaths to matter in the aggregate. 


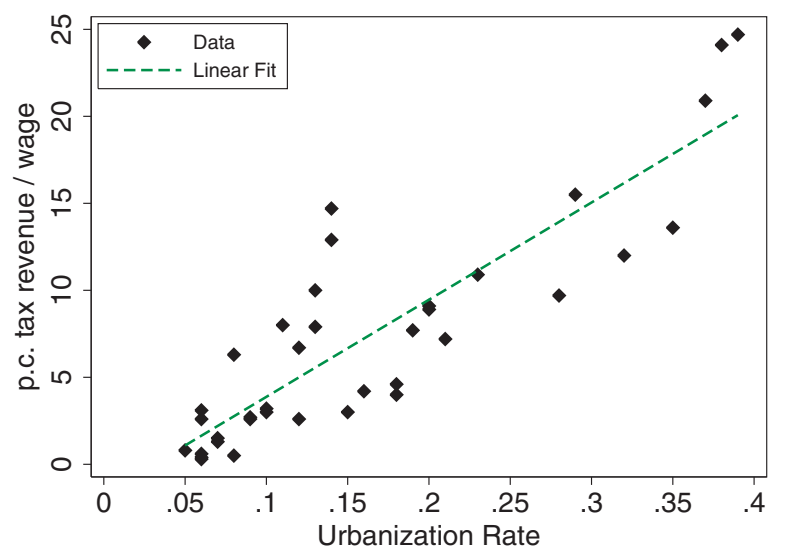

FIGURE 3

Tax revenues and urbanization. Notes: Urbanization rates: Bairoch et al. 1988) for population in cities larger than 5000 inhabitants, divided by country-level population from McEvedy and Jones 1978); see Appendix A.1 for details. Tax revenues (per capita in grams of silver, and as a percentage of average wages) from Karaman and Pamuk 2010). The dataset contains 7 countries with observations in 50-year intervals between 1509 and 1759, as well as 1789. The linear regression line has a slope parameter of 55.84 with a $t$-statistic of 9.98 and an $R^{2}$ of 0.76

be expropriated. As a result of the so-called 'commercial revolution' of the late Middle Ages, the economy had already become more urban, monetized and commercialized Lopez, 2008). Surpluses could be taxed more easily, providing the means for fighting more, and fighting longer. In Figure 3 we show the tight link between urbanization rates and tax revenue per capita (as a percentage of the average wage), between 1500 and 1800 (the correlation coefficient is 0.87) 26 China in the early modern period saw markedly less warfare than Europe Pomeranz, 2000. Even on a generous definition, wars and armed uprisings only occurred in one year out of five, no more than a quarter of the European frequency 27 Why did Europe see much more inter-state conflict than other parts of the globe? Tilly 1992) emphasizes the fragmented nature of the European political system in the late medieval period. In addition, after the Reformation, religious strife contributed to frequent warfare Jones, 1981). Compared to that, politically unified states like China had many fewer "flash points" leading to military conflict.

Not only were wars fewer in China after 1400. They also caused fewer epidemics. Europe is geographically subdivided by rugged mountain ranges and large rivers, with considerable variation in climatic conditions. China's main population areas were more homogenous in geographical terms than Europe's. The history of epidemics in China suggests that by 1000 AD, disease pools had become largely integrated (McNeill, 1977). Hence, troop movements produced less of a surge in Chinese death rates than in Europe 28

Pre-modern wars were deadly, but they destroyed little capital. Military technology was too primitive to cause widespread destruction. De Vries 1976) concluded that "it is hard to prove that military action checked the growth of the European economy's aggregate output". Malthus

26. We normalize by the wage since this shows that the growth in tax revenue does not simply reflect higher incomes. Instead, it shows that tax revenues grew disproportionately as urbanization increased.

27. Counting battles (instead of wars) reinforces this result-there were 1071 major battles (not peasant revolts, etc.) in Europe between 1400 and 1800. The corresponding figure for China is 23 Jaques 2007).

28. We are indebted to David Weil for this point. Weil 2004 shows the marked similarity of agricultural conditions in large parts of modern-day China. 
himself noted the remarkable ability of early modern economies to bounce back from war-induced destruction 29

Several factors kept economic losses small. Pay constituted the single largest expenditure item in war, and was largely recycled in the local economy. Destruction of capital mattered less where it could be rebuilt quickly. Wooden houses were easy to reconstruct 30 Where fields went untended, agricultural productivity rose-fallowing increased land fertility. Farm animals have high natural fertility rates, and losses of livestock can be made up quickly. Finally, warinduced mortality, where it resulted from poor nutrition, was probably concentrated amongst the more vulnerable groups - the young and the elderly (Tallett, 1992). Thus, war also reduced the dependency burden.

In our baseline modelling, we will assume that war shifted the mortality schedule, but that it did not affect productivity. We also examine the effects of negative productivity from warfare in Appendix A.8. While this changes the short-term dynamics, we show that our long-run results are unaffected.

2.2.4. Trade. Trade in early modern Europe frequently spread disease. The Black Death's advance in the 14th century followed trade routes Herlihy, 1997). The last outbreak in Europe is also linked to long-distance trade. A plague ship from the Levant docked in Marseille in 1720 , infecting the local population. It is estimated that 50,000 out of 90,000 inhabitants died in the subsequent outbreak Mullett 1936). As transport infrastructures improved, trade increased massively between the medieval period and the eighteenth century. Canals and better coastal shipping made it possible to trade bulky goods. Since trade increases with per capita incomes, the positive effect of the Black Death on wages created knock-on effects. These raised mortality rates yet further. Finally, there were interaction effects between the channels we have highlighted. The effectiveness of quarantine measures, for example, often declined when wars disrupted administrative procedure Slack, 1981). All these factors in combination ensured that, after the Black Death, European death rates increased, and stayed high, in a way that is unlikely to have occurred in other parts of the world.

\subsection{European economic performance and the first divergence between Europe and China}

After 1350, European per capita incomes surged ahead of those in other parts of the world, most notably China - a "First Divergence" occurred long before the Industrial Revolution. In addition to the real wage evidence discussed above, this conclusion is supported by urbanization rates. These have been widely used as an indicator of economic development (e.g. Acemoglu et al., 2005). Urbanization rates support the view that Europe's economy performed well during the early modern period. By this measure, Europe overtook China at some point between 1300 and 1500 , extending its lead thereafter. Figure 4 summarizes the evidence. We use data from Bairoch et al. 1988) and De Vries to construct a consistent series for the period 1000-1800 31 There is a sharp acceleration of urban growth after the 1350 , with the percentage of the population

29. "The fertile province of Flanders, which has been so often the seat of the most destructive wars, after a respite of a few years, has appeared always as fruitful and as populous as ever. Even the Palatinate lifted up its head again after the execrable ravages of Louis the Fourteenth" Malthus, 1798.

30. After the Turkish siege of Vienna in 1683, the Venetian ambassador marvelled at the fact that "the suburbs ... as well as the neighbouring countryside ... have been completely rebuilt in a short space of time" Tallett, 1992).

31. De Vries 1984) uses a cut-off of 10,000 inhabitants to define cities, and shows that the proportion of Europeans living in urban centers grew from $5.6 \%$ to $9.2 \%$ between 1500 and 1700 . His figures only start in 1500 . We extend this series using Bairoch et al. 1988). Appendix A.1 provides a detailed description of our method. 


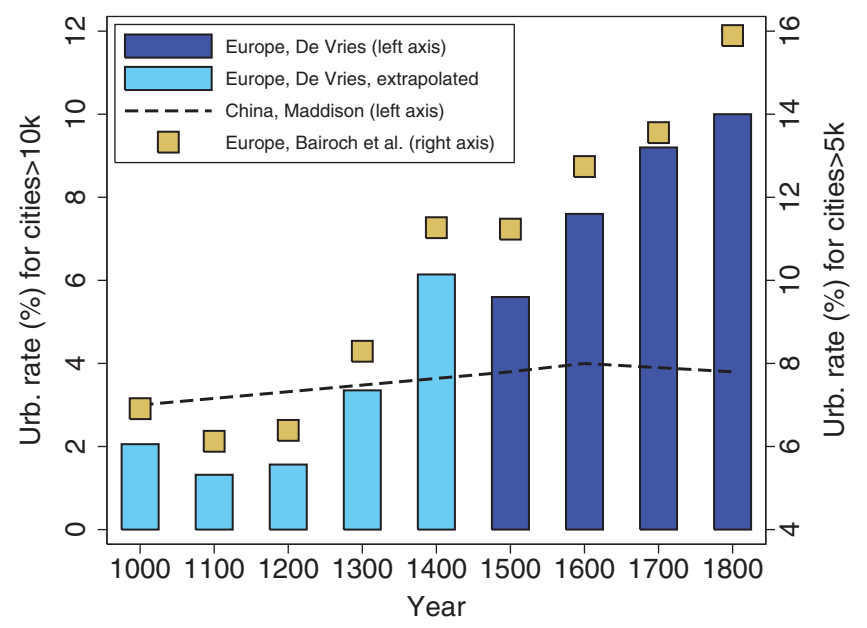

FIGURE 4

Urbanization rates in Europe and China, 1000-1800. Sources: De Vries 1984) for European urbanization rates 1500-1800, corresponding to cities with more than 10,000 inhabitants. Bairoch et al. 1988) for population in cities larger than 5000 inhabitants between 1000 and 1800, divided by country-level population from McEvedy and Jones 1978) to obtain urbanization rates; see Appendix A.1 for details. A regression-based technique in the spirit of Chow and Lin 1971) is used to extrapolate De Vries figures based on Bairoch et al.'s numbers. China: Maddison

2001, tables 1-8c and B-14); the line interpolates in 1100-1400 and 1700

living in cities (with more than 10,000 inhabitants) rising from about 3\% to $9 \%$ percent during the three centuries after the Black Death 32

Other regions of the world did not experience similar, sustained growth during this period. The contrast in economic performance with China is particularly instructive. Adam Smith had no doubt that the "real recompense of labour is higher in Europe than in China" Smith, 1776). Malthus and many other scholars agreed Elvin, 1973; : Jones, 1981). While the most pessimistic interpretations of Chinese economic performance have been challenged by the "California School", there is convincing evidence that European output per capita by the end of the early modern period was markedly higher 33

For example, the proportion of the Chinese population living in cities reached $3 \%$ in the mid-T'ang dynasty (762), 3.1\% in the mid-Sung dynasty (1120), and probably stagnated at the 3-4\% level thereafter until the 19th century Maddison, 2001; see the dashed line in Figure 4. Eastern Europe had low rates of urbanization overall, and it only saw minor increases after 1500. De Vries 1984) shows gains of $1.5 \%$ for the period 1500-1700. Similarly, the Middle Eastwhile highly urbanized on some measures - stagnated in terms of urbanization between 1100 and 1800 Bosker et al., 2008).

Wage data point in the same direction. Expressed as units of grain or rice, English wages were markedly higher throughout the early modern period than Chinese ones: Chinese grainequivalent wages were $87 \%$ of English ones in 1550-1649, falling to $38 \%$ in $1750-1849$

32. Prior to the Black Death, Medieval Europe did not experience a similar upward trend in urban population shares. Urban growth per century was about three times faster in 1300-1700 than in 1000-1300. (Buringh and Van Zanden, 2009).

33. Pomerand 2000 compares England with the Yangtze delta, China's most productive area. He concludes that Chinese peasants' incomes were similar or higher in terms of calories than those of English farmers. His work receives support from $\mathrm{Li}$ 1998, who presents optimistic conclusions about grain production in Jiangnan. 
Broadberry and Gupta 2006). Expressed in units of silver, the differences are even more striking. Allen 2009) finds that Chinese hired farm laborers earned only one third of the wage of their English peers 34

By the late 18th century, English agriculture released labor on a massive scale to the cities. In contrast, Chinese agriculture did not release labor; it hoarded it. Allen 2009) shows that output per year and head probably fell by $40 \%$ between 1620 and 1820 in Chinese agriculture, as average farm size declined. He concludes that "real wage comparisons push the start of the "Great Divergence" back from the nineteenth century to the seventeenth." This is the view that underlies our interpretation-Chinese output per capita, while not necessarily below the European norm at the beginning of the early modern period, stagnated or fell for most of it. In contrast, wages and incomes grew in Europe.

2.3.1. Chinese vs. European demography. Our model explains the first divergence between Europe and China as a result of demographic differences and interactions with the political environment. Demography differed substantially between the two regions. Chinese demographic growth was much more rapid than in Europe: population in China grew by $170 \%$ between 1500 and 1820; in Europe, the corresponding figure is 38\% 35 A long tradition of scholarship emphasized differences in fertility-Europeans practiced fertility limitation, by postponing marriage and having a high percentage of women that never married. In China, marriage occurred early and was universal 36

\section{THE MODEL}

In this section, we describe the two-sector Malthusian model summarized in the introduction (see Figure 10. The economy is composed of $N$ identical individuals who work, consume, and procreate. $N_{A}$ individuals work in agriculture $(A)$ and live in the countryside, while $N_{M}$ agents live in cities producing manufacturing output $(M)$. Production takes place under perfect competition. For simplicity, we assume that there is no physical capital or storage; wages are the only source of income. Labour mobility ensures that rural and urban wages equalize. Peasants own their land and pass it on to their children; when peasants migrate to cities, their land is distributed equally among the remaining rural population 37 Agricultural output is produced using labour and a fixed land area. This implies decreasing returns in food production. Manufacturing uses labour only

34. At the same time, peasant farmers who tilled their own soil may have done better than their English contemporaries in the 17th century. Thereafter, English earnings overtook Chinese ones Allen, 2009).

35. Maddison 2007); Lee and Feng 1999) also show Chinese population grew faster than the world on average.

36. Recent research instead argues that fertility rates were not too different overall, with infanticide and low fertility within marriage reducing Chinese birth rates Lee and Feng, 1999. With comparable fertility rates but much faster population growth in China, mortality rates overall there must have been lower than in Europe. Since income per capita was below the European level, fertility rates controlling for income were markedly higher in China, while mortality was lower. In other words, given how rich Europeans were, they should have lived longer and had more children if Europe and China had shared a demographic regime. Instead, Europeans died early and had few children despite their riches. This article explains why this does not constitute a paradox, by arguing that specific European factors driving up mortality rates pushed up per capita incomes.

37. Migration in the opposite direction is irrelevant in our model. Our setup can be interpreted as a reduced form of a more general model with a continuum of representative infinitely lived dynasties. Fertility and mortality depend on consumption, and we assume for simplicity that parents ignore (or do not internalize) the utility of their children as well as the link between demography and consumption. Thus, similar to Blanchard 1985, individuals face a given probability of death in each period, and a given fertility that is realized during the last period of life. Upon death, children inherit the property rights of land in equal shares. Under these assumptions, the dynamic problem reduces to a sequence of static problems that we model below. 
and is subject to constant returns to scale. Preferences over the two goods are non-homothetic and reflect Engel's law: the share of manufacturing expenditures (and thus the urbanization rate $\left.N_{M} / N\right)$ grows with p.c. income. Technology parameters in both sectors, $A_{A}$ and $A_{M}$, are fixed throughout the main part of our analysis. We introduce exogenous technological change below in Section 4.3 where we analyse its contribution to the "Rise of Europe".

A proportional tax $\tau$ on manufactured goods provides the funds for warfare-the higher tax revenues, the larger the proportion of population affected. Wars spread diseases. As the scale of warfare rises, more distant, less immune populations are affected; aggregate mortality surges. However, this rise only continues until the entire population has been affected. Beyond this point, additional warfare does not raise mortality.

\subsection{Consumption}

Each individual supplies one unit of labour inelastically in every period. There is no investmentall income is spent on agricultural goods $\left(c_{A}\right)$ and manufactured goods $\left(c_{M}\right)$. Agents choose their workplace in order to maximize income. When migration is unconstrained, this equalizes urban and rural wages: $w_{A}=w_{M}=w 38$ The resulting budget constraint is $c_{A}+p_{M} c_{M} \leq w$, where $p_{M}$ is the price of the manufactured good. The agricultural good serves as the numeraire. Before individuals buy manufactured goods, they need to consume a minimum quantity of food, $\underline{c}$. We refer to $\underline{c}$ as the subsistence level. Below it, individuals suffer from hunger, but do not necessarily die-mortality increases continuously as $c_{A}$ falls below $\underline{c}$. While the wage rate is below $\underline{c}$, any increase in income is spent on food. Preferences take the Stone-Geary form and imply the composite consumption index:

$$
u\left(c_{A}, c_{M}\right)= \begin{cases}\left(c_{A}-\underline{c}\right)^{\alpha} c_{M}^{1-\alpha}, & \text { if } c_{A}>\underline{c} \\ \phi\left(c_{A}-\underline{c}\right), & \text { if } c_{A} \leq \underline{c}\end{cases}
$$

where $\phi>0$ is a constant. Given $w$, consumers maximize 11 subject to their budget constraint. In a poor economy, where income is not enough to ensure subsistence consumption $\underline{c}$, the malnourished peasants are unwilling to trade food for manufactured goods at any price. Thus, the demand for urban labour is zero, and there are no cities. All individuals work in the countryside: $N_{A}=N$, while $\left(c_{A}=w_{A}<\underline{c}\right)$.

When agricultural output per capita is high enough to provide above-subsistence consumption $\left(w_{A}>\underline{c}\right)$, expenditure shares on agricultural and manufacturing products are:

$$
\begin{aligned}
\frac{c_{A}}{w} & =\alpha+(1-\alpha)\left(\frac{\underline{c}}{w}\right) \\
\frac{p_{M} c_{M}}{w} & =(1-\alpha)-(1-\alpha)\left(\frac{\underline{c}}{w}\right)
\end{aligned}
$$

Once consumption passes the subsistence level, peasants start to spend on manufacturing goods. These are produced in cities, which grow as a result. If income increases further, the share of spending on manufactured goods grows in line with Engel's law, and cities expand. The relationship between income and urbanization is governed by the parameter $\alpha$. Higher $\alpha$ implies more food expenditures and thus less urbanization at any given income level.

38. In the following, the subscripts $A$ and $M$ not only represent agricultural and manufacturing goods, but also the locations of production, i.e. countryside and cities, respectively. Higher city mortality arguably lowers the utility of urban workers. In the working paper version Voigtländer and Voth, 2008) we take this fact into account for endogenous individual workplace decisions. As a result, urban wages are above their rural counterparts, compensating for higher city mortality. While adding historical realism, this more complicated setup does not affect our main results. 


\subsection{Production}

Both agricultural and manufactured goods are homogenous and are produced under perfect competition. In the countryside, peasants use labour $N_{A}$ and land $L$ to produce food. The agricultural production function is

$$
Y_{A}=A_{A} N_{A}^{\beta} L^{1-\beta}
$$

where $\beta$ is the labour income share in agriculture. Because peasants own their land, agricultural wages are equal to the output per rural worker:

$$
w_{A}=A_{A}\left(\frac{L}{N_{A}}\right)^{1-\beta}=A_{A}\left(\frac{l}{n_{A}}\right)^{1-\beta}
$$

where $l=L / N$ is the land-labour ratio and $n_{A}=N_{A} / N$ is the labour share in agriculture, or rural population share. Since land supply is fixed, increases in population reduce the land-labour ratio and curtail agricultural wages. Manufacturing goods are produced in cities using the technology

$$
Y_{M}=A_{M} N_{M}
$$

Manufacturing firms maximize profits and pay wages $w_{M}=p_{M}(1-\tau) A_{M}$, where $p_{M}$ is the price of manufacturing goods and $\tau$ is a proportional tax on manufacturing products that is used to finance warfare (see below). The manufacturing labour share $n_{M}$ is identical to the urban population share.

Figure 5 illustrates the basic income-demand-urbanization mechanism of our model. If the rural wage (horizontal axis) is below subsistence (normalized to $\underline{c}=1$ ), the malnourished population does not consume any manufacturing goods. Cities do not exist (zero urbanization, left axis), and there are no workers employed in manufacturing (zero urban wages, right axis). Cities emerge once peasants' productivity is high enough for consumption to rise above subsistence; manufacturing production starts. Without constraints on migration, urban and rural wages equalize. As productivity increases further, urbanization and wages grow in tandem.

\subsection{Disease environment and population dynamics}

Individuals are distributed across a continuum of locations within a circle around a central location 39 Each location is characterized by its remoteness $r$ from the center. Remoteness is normalized to the interval $r \in[0,1]$, and population density decreases with remoteness: $\rho_{r}=N /(2 \pi r)$, where $N$ is total population. This implies that the number of individuals is constant along each circumference with distance $r$ from the center: $N(r)=N, \forall r$, which simplifies the following analysis.

At each location, we differentiate between infected and susceptible individuals 40 Their shares in the local population are given by $I(r)$ and $S(r)$, respectively. Thus, $I(r)+S(r)=1$. In each

39. The central location may be interpreted as the capital, but not as the only city-we assume that the composition of population in terms of urban vs. rural is the same everywhere in the circle.

40. This is similar in spirit to the standard S(usceptible)I(nfected)R(ecovered) epidemic model. For an overview of epidemiological models see Brauer and Castillo-Chávez 2001). While epidemic models in the spirit of Kermack and McKendrick 1927) describe the transmission of diseases within a population over time, we are interested in the transmission across space-from a central location to remote areas. We therefore modify the setting to reflect the spatial dimension. 


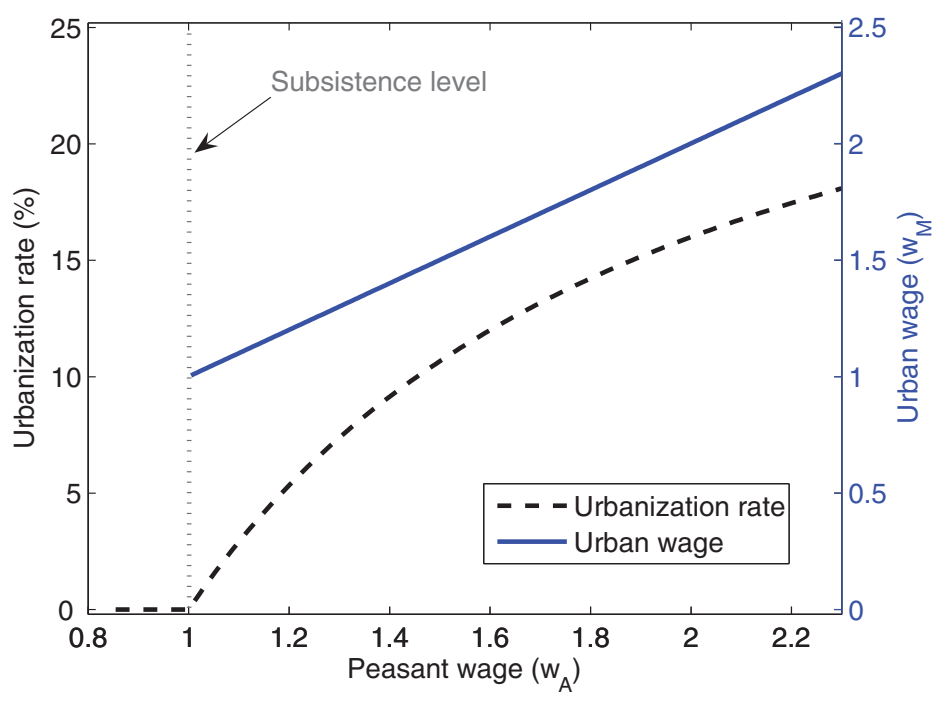

FIGURE 5

Wages and urbanization

period, a new disease spreads from the central location, where everybody is infected $(I(0)=1) 4$ Transmission from the center follows the rule:

$$
I(r)=\lambda(r) S(r) I(0)=\lambda(r) S(r) .
$$

where $\lambda(r)<1$ is the contact rate between regions with remoteness $r$ and the center. Each individual from the center makes contact with $\lambda(r) N$ individuals in $r 42$ At the same time, the fraction $S(r)$ is susceptible at remoteness $r$, and the share $I(0)$ of individuals in the center is infected. Multiplying these three components yields the number of infected individuals in regions with remoteness $r: \lambda(r) S(r) I(0) N$, and the corresponding share is given by $\square$. We assume $\lambda(r)=1-r$, i.e. the rate of contact with the central disease pool falls linearly in remoteness 43 Thus, the proportion of local population affected by disease outbreaks declines with distance from the center. For simplicity, we assume that individuals are myopic with respect to the location-specific odds of being infected, so that the settlement pattern is unaffected.

We can now derive the share of infected individuals in regions with remoteness $r$ due to the baseline spread of diseases (i.e. in an environment without additional mobility due to warfare or trade):

$$
I_{B}(r)=\lambda(r) \cdot 1=\lambda(r)=1-r,
$$

where we used the fact that initially all individuals are susceptible to a new disease $(S(r)=1)$. Integrating this expression over all regions $r \in[0,1]$ yields the baseline share of infected in the

41. We think of diseases as both common illnesses that mutate frequently (e.g. the flu), as well as periodically returning epidemics such as typhus, smallpox, or the plague. Because we focus on one period only for each disease outbreak, we implicitly assume that the recovery rate is zero, i.e. people are either infected or still susceptible.

42. It is not important for our results whether contact occurs directly between individuals from the center with those in regions with remoteness $r$, or indirectly via individuals in intermediate regions.

43. This is the simplest functional form that ensures that $I(r)$ is continuous at $r=0$ and that the most remote region is never subject to germs $(I(1)=0)$. 
overall population: $I_{B}=0.5$. Mortality among infected individuals falls with food consumption $c_{A}$. This is motivated by the fact that diseases are generally deadlier when the infected are malnourished. Specifically, the baseline mortality rate in the overall population is given by:

$$
d_{B}=I_{B} \cdot k_{B} \cdot\left(c_{A} / \underline{c}\right)^{\varphi_{d}}=\underline{d} \cdot\left(c_{A} / \underline{c}\right)^{\varphi_{d}},
$$

where $k_{B}$ is the rate at which diseases kill infected individuals at subsistence consumption, and the parameter $\varphi_{d}<0$ is the elasticity of mortality with respect to food consumption. For use in the calibration section, we define $\underline{d} \equiv I_{B} \cdot k_{B}$ as the baseline death rate at subsistence income.

3.3.1. The "Horsemen effect". Three factors add to baseline mortality when income grows beyond subsistence: War, trade, and urbanization. We model the scale of war and trade as a function of income and combine the result with the simple epidemic theory outlined above. We derive a function where (i) death rates initially rise quickly as incomes increase above subsistence and (ii) the increase slows and eventually flattens out as additional army movements and rising trade no longer bring previously unexposed populations into contact with new germs. Finally, excess city mortality also raises aggregate death rates, albeit to a smaller extent than warfare and trade.

We begin by linking tax revenues to warfare. Early modern taxation focused primarily on excess consumption; it was infeasible for below-subsistence income. In our setup, manufacturing output rises hand-in-hand with above-subsistence income. We thus model tax revenues as a proportional share $\tau$ of manufacturing output:

$$
T=\tau p_{M} Y_{M}
$$

Tax revenues are an increasing function of the urbanization rate $n_{M}$ (cf. Figure 3 ). For belowsubsistence income, i.e. when urbanization is zero, no taxes are collected. Tax revenues are used to pay and equip soldiers, and to maintain them in the field. A part of the cost of an army is fixed, denoted by $F_{W} 44$ The more tax revenues are available, the larger is the scale of warfare $(W) . W$ thus reflects how deep the pockets of sovereigns are, how long they fight, and how large their armies consequently are, relative to the size of the overall population:

$$
W=\max \left\{0, \frac{1}{N} A_{W}\left(T-F_{W}\right)\right\}
$$

where $A_{W}$ reflects belligerence, i.e. how strongly tax revenues translate into warfare. The larger $W$, the more remote territories are traversed by armies on the march. More intense wars last longer, and the armies will keep on the move for longer as well. In addition, more intense war means bigger armies relative to overall population. Larger armies often marched and fought in separate corps for strategic and logistical reasons, making it more likely that remote areas were affected. Let $R \in[0,1]$ denote the most remote area affected by troop movements, which increases with the scale of warfare:

$$
R=\min \{W, 1\}
$$

For a large-enough $W$, all territories are affected by warfare; an increase of $W$ beyond 1 does not lead to additional disease spread via wars. This explains why the impact of warfare on mortality is limited.

44. Early modern states typically spent $80 \%$ of their revenue on war Bean 1973). Fixed costs in early modern warfare are related to fortifications and standing armies. The role of economies of scale as one of the drivers behind the rise of larger states after 1500 is discussed by Bean 1973). 
If a region is affected by warfare, there is an additional source of disease in the form of infected soldiers. The number of additional infections caused by warfare depends on the share of susceptible individuals in a region, i.e. individuals who have not been infected yet via the baseline transmission of diseases. Following 77 , the share $S_{B}(r)=1-I_{B}(r)=r$ of individuals remains susceptible after the baseline transmission. The more remote an area, the larger the fraction of susceptible individuals - the extremely high mortality in the Americas upon the arrival of the Conquistadors illustrates the mechanism.

Additional disease spread by infected soldiers also follows the transmission from the center described in [6] ${ }^{45}$ If warfare reaches a region with remoteness $r$, the share of additionally infected individuals is thus given by:

$$
I_{W}(r)=\lambda(r) S_{B}(r) I(0)=\lambda(r) r=(1-r) r .
$$

Warfare reaches all regions with remoteness $r \leq R$. In even more remote regions, there are no additional infections due to warfare. Therefore, we obtain:

$$
I_{W}(r)= \begin{cases}(1-r) r, & \text { if } r \leq R \\ 0, & \text { if } r>R\end{cases}
$$

Next, we derive the average economy-wide share of individuals that are infected due to warfare. Integrating over $r \in[0,1]$ yields:

$$
I_{W}(R)=\int_{0}^{1} I_{W}(r) d r=\int_{0}^{R}(1-r) r d r=\frac{1}{2} R^{2}-\frac{1}{3} R^{3} .
$$

We show below that $R$ is an increasing function of the urbanization rate $n_{M}$, so as to obtain $I_{W}\left(n_{M}\right)$. Following the same setup as for baseline mortality in 8 , the war-related additional death rate is thus given by

$$
d_{W}=I_{W}\left(n_{M}\right) \cdot k_{B} \cdot\left(c_{A} / \underline{c}\right)^{\varphi_{d}}=h_{W}\left(n_{M}\right) \cdot \underline{d} \cdot\left(c_{A} / \underline{c}\right)^{\varphi_{d}},
$$

where $h_{W}\left(n_{M}\right) \equiv I_{W}\left(n_{M}\right) / I_{B}$ is the war-related "Horsemen effect", i.e. the percentage increase in infections (and thus aggregate mortality) due to warfare.

Trade spreads disease in a similar fashion as warfare. Trade increases with manufacturing output, and the fixed cost in (10) can be interpreted as expenses for trade infrastructure. The effect of trade on death rates can thus be modelled along the same lines as warfare, such that $h_{W}\left(n_{M}\right)$ represents both war- and trade-related disease spread.

Finally, higher urbanization raises aggregate death rates because city mortality is above the baseline level. We represent this fact by a higher death rate of infected individuals in cities, $k_{M}>k_{B}$. With the proportion $n_{M}$ of individuals dwelling in cities, the corresponding additional impact on aggregate death rates is given by $h_{M}\left(n_{M}\right)=\left(k_{M} / k_{B}-1\right) \cdot n_{M}{ }^{46}$ This is the urbanizationrelated "Horsemen effect". Aggregate death rates are given by baseline mortality, augmented by

45. Thus, the chance that a disease transmitted by armies reaches a given region is declining in remoteness. The greater the distance to the origin of an army's march, the smaller the remaining size of an army typically is, and the lower the chance that it will cross a given city at this distance - the perimeter of a circle around the central location increases linearly in distance to the center.

46. More specifically, urban death rates are given by $d_{M}=I_{B} \cdot k_{M} \cdot\left(c_{A} / \underline{c}\right)^{\varphi_{d}}=\left(k_{M} / k_{B}\right) \cdot \underline{d} \cdot\left(c_{A} / \underline{c}\right)^{\varphi_{d}}$. We thus assume that the share of infected is the same in urban and rural areas, while the deadliness of diseases is different. Alternatively, we could assume that the rate of infections is larger in cities, which would yield identical results. 
war, trade, and urbanization:

$$
d=\left[1+h_{W}\left(n_{M}\right)+h_{M}\left(n_{M}\right)\right] \cdot \underline{d} \cdot\left(c_{A} / \underline{c}\right)^{\varphi_{d}}=\left[1+h\left(n_{M}\right)\right] \cdot \underline{d} \cdot\left(c_{A} / \underline{c}\right)^{\varphi_{d}},
$$

where $h\left(n_{M}\right)$ denotes the aggregate "Horsemen effect". When the Horsemen ride, increasing income has an ambiguous effect on mortality. On the one hand, the Horsemen raise background mortality. On the other hand, greater food consumption translates into lower baseline death rates in (8). The aggregate impact of income on mortality depends on the model parameters. Our calibration in Section 4.1 demonstrates that death rates increase in income-and thus in urbanization - over some range, following an S-shaped pattern as shown in the right-hand panel of Figure 1

3.3.2. Population dynamics. Birth rates depend on nutrition, measured by food consumption $c_{A}$. Individuals procreate at the rate

$$
b=\underline{b} \cdot\left(c_{A} / \underline{c}\right)^{\varphi_{b}}
$$

where $\varphi_{b}>0$ is the elasticity of the birth rate with respect to nutrition, and $\underline{b}$ represents the birth rate at subsistence consumption.

Population growth equals the difference between the average birth and death rate, $\gamma_{N}=b-d$, where the latter can include the "Horsemen effect". The law of motion for aggregate population $N$ is thus

$$
N^{\prime}=(1+b-d) N,
$$

where $N^{\prime}$ denotes next period's population. Births and deaths occur at the end of a period, such that all individuals $N$ enter the workforce in the current period.

\subsection{Steady states}

A steady state in our model is characterized by constant output per worker, labour shares, wages, prices, and consumption expenditure shares. We begin by analysing the economy without technological progress; in this case, population is also constant in steady state, so that 18) implies $b=d 47$ Equating (16) and (17) yields an expression that implicitly defines steady state income and illustrates the intuition behind the "Horsemen effect".

$$
\frac{c_{A}^{*}}{\underline{c}}=\left(\left(1+h^{*}\right) \cdot \frac{d}{\underline{b}}\right)^{\frac{1}{\varphi_{b}-\varphi_{d}}},
$$

where the asterisk denotes steady state levels. Because $\varphi_{b}-\varphi_{d}>0$, an increase in death rates due to the "Horsemen effect" $h^{*}$ raises per capita food consumption (and thus income) in steady state. Multiple steady states can arise if the function $h\left(n_{M}\right)$ increases in urbanization (and thus income) over some range. The steady state level of variables depends on the position of the birth and death schedules. Figure 1 visualizes the shape of the schedules, depicting the S-shaped pattern of aggregate mortality as implied by 160

Points $E_{0}$ and $E_{H}$ in Figure 1 are stable steady states with endogenous population size. During the transition to steady state, population dynamics influence the land-labour ratio and thus output per worker. Consequently, wages, expenditure shares, prices, and labour shares all change during the transition. In the following, we analyse these dynamics.

47. In the presence of ongoing technological progress, population grows at a constant rate (see Section 4.3 .

48. Figure 1 refers to a simple one-sector setup. Because food consumption $c_{A}$ is proportional to wages (see Equation 2), we can use the same figure to illustrate the intuition in our two-sector model. 


\subsection{Solving the dynamic model}

3.5.1. The economy with below-subsistence consumption. To check if agricultural productivity (determined by $A_{A}$ and the land-labour ratio) is sufficient to ensure above-subsistence consumption, we construct the indicator $\widehat{w}$, assuming that all individuals work in agriculture. Equation (3) with $N_{A}=N$ gives the corresponding per-capita income:

$$
\widehat{w} \equiv \frac{Y_{A}(N)}{N}=A_{A}\left(\frac{L}{N}\right)^{1-\beta}
$$

If $\widehat{w} \leq \underline{c}$, all individuals work in agriculture and spend their entire income on food. Since there is no demand for manufacturing goods $\left(c_{M}=0\right)$, the manufacturing price is zero. This implies zero urban wages and zero city population $\left(w_{M}=0\right.$ and $\left.n_{M}=0\right)$. In addition, $w_{A}=c_{A}=\widehat{w}$, which can be used in 160 and 177 to derive population growth 49 These equations characterize the economy with below-subsistence consumption. In principle, our model can have a steady state with belowsubsistence consumption, such that the economy is completely agrarian. This is the case if death rates are generally low. However, urbanization rates were not zero in Europe even before the Black Death, so that our calibration below features both $E_{0}$ and $E_{H}$ with above-subsistence consumption.

3.5.2. Above-subsistence consumption. If $\widehat{w}>\underline{c}$, agricultural productivity is high enough for consumption levels to rise above subsistence. Following (2), well-nourished individuals spend part of their income on manufacturing goods. To produce them, a share $n_{M}$ of the population lives and works in cities. In each period, individuals choose where to live and work. Wage increases (e.g. driven by shocks to population) lead to more manufacturing demand and spur migration to cities, which occurs until $w_{M}=w_{A}$. For small income changes, migration responses are minor, and cities can absorb enough migrants to establish this equality immediately. We refer to this case as unconstrained city growth. Goods market clearing together with Equations (2), (3), 5), and (9) imply5

$$
\begin{aligned}
A_{A} N_{A}^{\beta} L^{1-\beta} & =[\alpha w+(1-\alpha) \underline{c})] N \\
(1-\tau) p_{M} A_{M} N_{M} & =[(1-\alpha)(w-\underline{c})] N, \text { if } \widehat{w}>\underline{c}
\end{aligned}
$$

Substituting $w=w_{M}=(1-\tau) p_{M} A_{M}$ into 22) and using $\left(1-n_{A}\right)=N_{M} / N$ yields the employment share in agriculture:

$$
n_{A}=\alpha+\frac{(1-\alpha) \underline{c}}{w}, \quad \text { if } \widehat{w}>\underline{c}
$$

The share of agricultural employment decreases in wages, while urbanization $n_{M}=1-n_{A}$ increases. The responsiveness of urbanization to wages is the stronger the smaller $\alpha-$ a result that we use to calibrate this parameter. To solve the model we also need the wage rate. Dividing (21) by $N$ yields

$$
\alpha w+(1-\alpha) \underline{c}=A_{A}\left[n_{A}(w)\right]^{\beta}\left(\frac{L}{N}\right)^{1-\beta},
$$

which says that per capita food demand (left-hand side) equals per capita production in agriculture (right-hand side), with the rural employment share $n_{A}$ depending on wages as given by 23]. This

49. Note that the "Horsemen effect" is zero because $n_{M}=0$; there are neither cities that raise aggregate mortality nor tax revenues that would support warfare.

50. Note that manufacturing production is split between consumption and tax revenues. The market clearing condition is thus: $p_{M} y_{M} N=p_{M} c_{M} N+\tau p_{M} y_{M} N$, so that $c_{M}=(1-\tau) y_{M}$. Substituting this in 2] yields 22. 
equation implicitly determines the wage rate for a given population size $N$. It has a unique solution; $w$ increases in $A_{A}$ and $L / N$. Given $w$ and $p_{M}=w /\left[(1-\tau) A_{M}\right]$, food and manufacturing consumption follow from (2), and the urbanization rate $n_{M}=1-n_{A}$ is determined by (23). Finally, we derive tax revenues as a function of urbanization. Using (9), 22, and 23) we obtain:

$$
T=\tau n_{M} \frac{(1-\alpha) \underline{c}}{1-\alpha-n_{M}} N
$$

which is strictly increasing in $n_{M}$ and defined for $n_{M}<1-\alpha$. Thus, urbanization rates cannot exceed the share of manufacturing in above-subsistence consumption. Together with 10) and (11), Equation (25) determines the most remote area affected by warfare, $R$, which is increasing in urbanization but zero as long as taxes are insufficient to cover the fixed cost of warfare. Using this result in 14] we obtain the share of additionally infected individuals due to warfare, $I_{W}$. The warrelated "Horsemen effect" is $h_{W}\left(n_{M}\right)=I_{W}\left(n_{M}\right) / I_{B}$. Adding the effect of city excess mortality, we obtain aggregate death rates from 116 . This also implicitly defines the functional form of the "Horsemen effect", which comprises three ranges: first, $h\left(n_{M}\right)$ increases only due to city excess mortality, while war-related disease spread is zero as long as tax revenues are below the fixed $\operatorname{cost} F_{W}$. Our calibration shows that in this range, the death schedule $d$ is downward-sloping. Because $T$ is increasing in $n_{M}$, there is a threshold urbanization level at which warfare begins to spread diseases. The larger the fixed cost $F_{W}$, the higher this threshold. Second, once this threshold is passed, $h\left(n_{M}\right)$ increases sharply due to war-related disease spread until the complete area is affected by warfare $(R=1)$. Third, beyond this point additional warfare does not increase death rates, and $d$ is again downward sloping.

The difference between birth rates from 17 and death rates $d$ yields population growth as a function of food consumption and urbanization. All calculations up to now have been for a given $N$. For small initial population, births outweigh deaths and $N$ grows until diminishing returns bring down p.c. income enough for $b=d$ to hold. The opposite is true for large initial $N$. To simulate the dynamic model, we derive $b$ and $d$ for given $N$, and population in the next period from 18 . The steady state is obtained where birth and death schedules intersect. The steady state level of population depends on the productivity parameters $A_{A}$ and $A_{M}$, and on the available arable surface, $L$. Wages in a given steady state, however, depend only on the intersection of the $b$ and $d$ schedules (see Figure 1), and are independent of the levels of $A_{A}, A_{M}$, or $L$.

\section{CALIBRATION AND DISCUSSION OF RESULTS}

Is the "Horsemen effect" powerful enough to explain an important part of the rise in European incomes, and of the divergence between Europe and China? To obtain multiple steady states in our model, death rates must rise substantially with income. We calibrate our model with and without the additional mortality that comes from war, trade, and urbanization. This provides a dynamic path of two economies - one a stylized version of Europe, the other of China. Parameters are chosen to match historically observed fertility, mortality, and urbanization rates. We then simulate the impact of the plague and derive the steady state levels of p.c. income and urbanization in the centuries following the Black Death. We also discuss the context and robustness of our results, as well as the implications of our key mechanism for relative prices.

\subsection{Calibration}

We proceed in six steps. First, we calibrate the relationship between wages, manufacturing demand, and urbanization. Second, we set initial parameters to match the pre-plague 
characteristics in Europe. Intuitively, this step locates the fertility and mortality schedule such that point $E_{0}$ in Figure 1 reflects pre-plague birth rates, death rates, and wages ( $w_{0}$, corresponding to information on 14th century urbanization $n_{M, 0}$ ). The second step also involves calibrating the slopes of the fertility and mortality schedule. In the third step, we use historical evidence to gauge the size of the "Horsemen effect". This is followed by the dynamic part of the "Horsemen effect" in the fourth step, where we calibrate the relationship between income and tax revenues, the fixed cost of warfare, and the belligerence parameter. Together, these determine the urbanization rate at which the "Horsemen effect" sets in, and the point where it reaches its maximum. Fifth, we set a parameter that constrains the speed of city growth - a dimension that adds historical realism to our model during the transition from $E_{0}$ to $E_{H}$, but does not influence the steady state outcomes. Finally, we modify two parameters that differentiate China from Europe: city excess mortality and belligerence. For the impact of the Black Death we use the same number for Europe and China: a population loss of $40 \%$. This is the mid-point of common estimates that report magnitudes between one-third and one half (Benedictow, 2004).

The structure of our model is flexible with respect to the length of a period 51 We choose annual periods. This ensures a detailed representation of population recovery during the years after the Black Death and enables us to model the short-run negative impact of warfare on productivity when analysing the robustness of our results.

Step 1: Engel's law: wages, manufacturing demand, and urbanization We begin by calibrating the relationship between the wage rate and manufacturing expenditures (and thus urbanization). For low wage levels $(w<\underline{c})$, all expenditure goes to food. With higher p.c. income, expenditure shares on manufacturing goods and urbanization both increase. This mechanism is driven by the relative demand for food vs. manufacturing products. We use $\alpha=0.68$, which implies an income elasticity of food expenditure between 0.7 and 0.8 over the relevant income range in our model. This is similar to the figure derived by Horrell 1996) for $18^{\text {th }}$ century England (0.76), and close to contemporary estimates from India (0.7, as reported by Subramanian and Deaton, 1996). In Appendix A.2 we show that our choice of $\alpha$ also implies a good fit for the historical relationship between wages and urbanization.

Step 2: initial steady state Next, we calibrate the parameters for the pre-plague steady state $E_{0}$ (Europe before the Black Death). The intersection of birth and death schedule determines per capita income and urbanization rates in steady state. Urbanization rates in Europe before the 14th century were approximately 2-3\% (data from de Vries, 1984 and Bairoch et al., 1988; see Figure 4 and Appendix A.1). We choose $n_{M, 0}=2.5 \%$. For cities to exist in $E_{0}$, wages have to be above subsistence, i.e. $w_{0}>\underline{c}$. This requires the intersection of $b$ and $d$ to lie to the right of $\underline{c}$. Thus, death rates must be higher than birth rates at the subsistence level, $\underline{d}>\underline{b}$. The intuition for this can be seen in Equation [19], where $\underline{d}>\underline{b}$ implies above-subsistence consumption even in the low-income steady state. The exact parameter values depend on the slope of the birth and death schedules. Kelly and Ó Grada 2008) estimate the elasticity of death rates with respect to income before the Black Death (1263-1348). We use the average of their results, $\varphi_{d}=-0.55$. This is very similar to the figures estimated by Kelly 2005) for the period 1541-1700 52 For the elasticity of birth rates with respect to real income, we use the estimate in Kelly 2005) of

51. See in particular the interpretation of our setup as a continuum of infinitely lived dynasties with probabilistic births and deaths in each period in footnote 37

52. Kelly and Ó Grada 2008) find $\varphi_{d}=-0.59$ for 20 large manors and -0.49 for the full sample of 66 manors. These numbers coincide with the one estimated by Kell 2005), who finds $\varphi_{d}=-0.55$ using weather shocks as a source of exogenous variation. Earlier estimates had yielded smaller elasticities (c.f.Lee 1981). 
$\varphi_{b}=1.4153$ Both $\varphi_{d}$ and $\varphi_{b}$ rely on estimates for England as a best-guess for Europe. This is a conservative assumption for our purposes, since the Poor Law is likely to have softened Malthus' "positive check" in England. Without the buffer of income support, death rates elsewhere are likely to have spiked more quickly in response to nutritional deficiencies. Regarding the level of annual birth and death rates in the pre-plague steady state, we use $b_{0}=d_{0}=3.0 \%$, which is in line with the rates reported by Anderson and Lee 2002). This, together with the elasticities and the pre-plague urbanization rate of $n_{M, 0}=2.5 \%$, implies $\underline{d}=3.02 \%$ and $\underline{b}=2.75 \%$.

In agricultural production, we use a labour income share $\beta=0.6$. This is similar to the value implied by Crafts 1985), and is almost identical with the average in Stokey's 2001) calibrations. For any steady state wage level derived from the intersection of $b$ and $d$, we can calculate the corresponding population $N 54$ We normalize $L=1$ and choose parameters such that initial population is unity $\left(N_{0}=1\right)$, and the price of manufacturing goods is $p_{M, 0}=155$ This involves the initial productivity parameters $A_{A, 0}=1.076$, and $(1-\tau) A_{M, 0}=1.087$, where the calibration of the latter is taking into account the proportional tax $\tau$ on manufacturing products. $A_{M, 0}$ can be derived once we obtain $\tau$ below. Since our baseline calibration refers to Europe, we take city excess mortality into account when deriving aggregate death rates in the pre-plague steady state.

Step 3: magnitude of the "Horsemen effect" We now turn to the calibration of the mortality regime in Europe, where the "Horsemen effect" raises death rates. The direct effect of urbanization comes into play as soon as people dwell in cities, where death rates are higher. As discussed in the historical overview section, death rates in European cities were approximately $50 \%$ higher than in the countryside, so that $k_{M} / k_{B}=1.5$. The term $h_{M}$ in Equation 16 captures the direct effect of urbanization on background mortality. On average, European urbanization grew from approximately 3-9\% between 1300 and 1700 (see Figure 45 56 This boosts average death rates by $0.05 \%$ in 1300 and $0.15 \%$ in 1700 (compared to a baseline mortality of $3 \%$ ). City mortality is, however, not the biggest contributor to higher average death rates.

After the Black Death, this direct effect is reinforced by the spread of diseases as a result of war and trade. These grow with p.c. income, exposing uninfected individuals to new germs. In our model, the war- and trade-related "Horsemen effect" is given by the share of additionally infected individuals $I_{W}$, relative to the baseline share of infected $I_{B}: h_{W}\left(n_{M}\right)=I_{W}\left(n_{M}\right) / I_{B}$. Recall from (7) that $I_{B}=0.5$, while (11) and (14) imply that the upper bound is $\bar{h}_{M}=(1 / 6) / 0.5=1 / 3$ (which is reached when the scale of warfare exceeds one, such that all territory is affected). Note that this number is directly implied by the simple parametrization in our model. We also provide detailed historical evidence suggesting that war- and trade-related excess death rates indeed raised background mortality by up to $1 / 3$.

53. These elasticities are bigger than the estimates in, say, Crafts and Mill 2008, or in Anderson and Lee 2002. Because of endogeneity issues in deriving a slope coefficient in a Malthusian setup, the IV-approach by Kelly is more likely to pin down the magnitude of the coefficients, compared to identification through VARs or through Kalman filtering techniques. For the same reason, we are not convinced that Malthusian forces weakened substantially in the early modern period, as argued by Nicolini 2007, Crafts and Mills 2008, and Galloway 1988).

54. For example, rural population is implicitly given by 4, and is the larger (for a given wage) the more land is available and the larger is $A_{A}$. We calculate the steady state by solving for birth and death rates for given $N$, and then iterate over population until $b=d$. This procedure gives the long-run stable population as a function of fertility and mortality parameters, productivity, and land area.

55. Other values of the relative price, resulting from different $A_{M, 0}$ relative to $A_{A, 0}$, do not change our results.

56. We use De Vries' cutoff level of 10,000 inhabitants to define a city. Evidence from England suggests that York $(12,000$ inhabitants) had similar life expectancy as London in the 16th and 17th centuries. Note that our choice is a conservative one-a cutoff of 5000 would deliver higher urbanization rates and thus a larger direct city mortality effect. 
In order to derive the maximum impact of warfare on mortality, we obtain the percentage of European population affected by war between 1500 and 1700. We describe the derivation of this measure in Appendix A.3 and plot it over time in Figure A.2; it grows from about $12 \%$ in 1500 to roughly $50 \%$ around 1700 , and decreases in the 18th century. The population share affected by wars mirrors the trend in the number of plague outbreaks shown in the left panel of Figure 2 as it should if wars were one of the main factors spreading disease in early modern Europe. In times of war, death rates nationwide could rise by 40-100\% (see Section 2 . The impact of war was local, but we focus on nationwide effects to match the construction of the war frequency variable, which also uses nations as the unit of analysis. Given steady state death rates of $3 \%$ per annum, this implies an additional 1.2-3\% under warfare. Throughout the second half of the 17th century - the 50-year period with the largest war frequency in early modern times-on average $38 \%$ of the European population were affected by wars. Based on this period, we derive the maximum war-related mortality increase:

Excess death under warfare $\times$ max. share of population affected $=[0.46-1.14 \%]$

In the baseline calibration, we use the center of this interval - a maximum war-related mortality increase of $0.75 \%$.

To this we add $0.25 \%$ for epidemics spread via trade. While we do not know with certainty how many extra deaths were caused by early modern trade, modern data can help to gauge magnitudes. Osten 2009) argues that in the case of HIV in Africa, a doubling of trade leads to between a doubling and a quadrupling of infections. If infectious disease in the pre-plague steady state accounted for only one death out of eight, an increase in the death rate by $0.25 \%$ is plausible 57 This probably constitutes a lower bound on death by diseases spread via trade routes-plague, typhoid, smallpox, and influenza are more infectious than HIV. Overall, our best guess for the total additional mortality due to warfare and trade is $1 \%$. Given the baseline mortality of about $3 \%$, this compares very well with the maximum "Horsemen effect" $\bar{h}_{M}=1 / 3$ that follows directly from our model.

The maximum "Horsemen effect" is reached during the 17th century, which saw savage warfare, with troop movements over a very wide area, and for extended periods (Levy, 1983). In the following, we use the mid-point of this century, 1650, to pin down the fixed cost $F_{W}$ and the belligerence parameter $A_{W}$.

Step 4: dynamic part of "Horsemen effect" Next, we calibrate the dynamic part of the "Horsemen effect"- the link between urbanization and warfare and trade. We begin with the relationship between urbanization and tax revenues by estimating Equation 25) for a panel of countries. We use tax revenue data from Karaman and Pamuk 2010) and obtain an estimate $\hat{\tau}=0.52$, i.e. the tax rate on above-subsistence income in early modern Europe was about

57. Our estimate is derived as follows: trade grows with elasticities of 0.8 and 0.65 with respect to income of country A and B, as in the gravity model estimated by Bergstran 1985, table 1, column 1). This implies that as overall income doubles, trade rises by $145 \%$. We focus on the period 1500-1700, where income data are available. In order to provide a conservative estimate, we consider only the per capita component of overall income growth. That is, we do not take into account the contribution of population growth to aggregate income increases, because growing population might reflect the convergence back to long-run levels after the Black Death. Using Bergstrand's elasticity, combined with the fact that p.c. incomes grew by approximately 30\%, suggests that trade may have increased by $44 \%$ during our period. Using the average elasticity of 1.5 from Oster 2009, infectious disease should have been $65 \%$ higher. For the aggregate death rate to increase by $0.25 \%$ as a result of more trade in 1700 , an annual $0.38 \%(=0.25 \% / 0.65)$ of the population must have fallen victim to infectious diseases before the plague. This corresponds to approximately one out of every 8 deaths in the pre-plague steady state. 
$50 \%$. This is equivalent to effective average tax rates of $5-12 \%$ between 1300 and 1700 , which tallies well with the tax-to-wage ratio in Figure 358 Detailed results are presented in Appendix A.4.

We proceed by deriving an estimate for $F_{W}$ from Equation [10. We use the total number of battles per 25-year period in Europe to capture the scale of warfare $W$, and combine it with information on tax revenues to reflect $T$. There were 374 battles in Europe between 1500 and 1790 Jaques, 2007). We estimate $W_{t}=\beta_{0}+\beta_{1} T_{t}+\varepsilon_{t}$ and interpret $\beta_{0}$ as fixed cost of warfare. Fixed costs as a proportion of total revenues, $\hat{\beta}_{0} / T_{t}$, fall from about $80 \%$ in 1550 to approximately $20 \%$ in the 17th century. This relationship is shown in Appendix A.4, which also provides more detail on the estimation. For our calibration, we use the value from the mid-17th century, when the "Horsemen effect" reached its maximum. This gives $F_{W} / T_{1650}=0.2$. Note that both $T$ and $F_{W}$ are scaled by population $N$ in 10 . We thus calibrate $t \equiv T / N$ and $f_{W} \equiv F_{W} / N$. To obtain $f_{W}$ in units consistent with our model, we derive $t_{1650}$ from 25, using the corresponding historical urbanization rates, $n_{M}, 1650$. Urbanization reached $8 \%$ in the mid-17th century (De Vries, 1984). The implied fixed cost of warfare is $f_{W}=0.2 \cdot t_{1650}=0.2 \cdot \tau n_{M, 1650}(1-\alpha) \underline{c} /\left(1-\alpha-n_{M, 1650}\right)=$ 0.011 . Finally, we calibrate the belligerence parameter $A_{W}$, using the fact that the war-related "Horsemen effect" reaches its maximum in the mid-17th century; thus, $W_{1650}=1$. Re-arranging 10), we obtain $A_{W}=W_{1650} /\left(t_{1650}-f_{W}\right)=22.54$.

As a consistency check of the calibrated parameters, we derive the urbanization rate at which per-capita tax revenues are large enough to cover the fixed cost of warfare $f_{W}$. Using (25), we calculate $\underline{n}_{M}$ such that $t\left(\underline{n}_{M}\right)=f_{W}$. This implies $\underline{n}_{M}=(1-\alpha) f_{W} /\left[\tau(1-\alpha) \underline{c}+f_{W}\right]=2.0 \%$. Recall that we calibrate our model such that urbanization in the low-income steady state is $n_{M, 0}=2.5 \%$. Thus, there is some warfare even before the Black Death. However, the effect on mortality is very small-in the lower part of the S-shaped mortality function-and not sufficient to push the economy towards the high-income steady state. In Appendix A.4, we show that an alternative calibration of $f_{W}$-based on a threshold level for taxation-yields very similar values.

Step 5: constraints on city migration In this step, we calibrate the limit to city migration. Migration from the countryside to cities was not immediate. Building new houses and enlarging cities was slow and costly. Migrants caused over-crowding, making further migration to the cities less attractive. To capture these difficulties during the transition phase, we assume that city growth was constrained (see Appendix A.5 for detail). While none of the long-run results depend on this assumption, we gain historical realism and can compare predicted transitional dynamics with the data. Immediately after the Black Death, migration into cities was largely unconstrained because many city dwellers had died. We assume that after the Black Death, overall city population can reach its pre-plague level immediately. Once this threshold is reached, we set the maximum urban growth equal to the 95th percentile of observed urbanization growth across 20 countries over the period 1400-1700. This implies $\bar{v}=0.46 \%$, based on data from Bairoch et al. (1988).

Step 6: Chinese parameters When simulating the Chinese economy, we use the same parameters as for Europe with two exceptions. First, there is no excess city mortality: $k_{M}^{\text {China }}=k_{B}$. Second, the frequency of war in China after 1400 was substantially lower than in Europe. As explained in Section 2 wars and armed uprisings in China occurred at no more than a quarter of the European frequency. We thus use $A_{W}^{\text {China }}=0.25 \cdot A_{W}^{\text {Europe }}$. This is a conservative estimate of

58. The relevant range for our calibration are urbanization rates between $3 \%$ and $9 \%$, i.e. the European numbers between 1300 and 1700. These are associated with p.c. incomes of about 10-30\% above subsistence in our model. Thus, the effective average tax rate implied by $\hat{\tau}=0.52$ is between $5 \%$ and $12 \%$. 
TABLE 1

Baseline calibration

\begin{tabular}{lll}
\hline Symbol & Interpretation & Value \\
\hline Parameters & Responsiveness of urbanization to income & \\
$\alpha$ & Labour share in agriculture & 0.68 \\
$\beta$ & Subsistence food consumption & 0.6 \\
$\underline{c}$ & Land & 1 \\
$L$ & Initial TFP in agriculture & 1.076 \\
$A_{A, 0}$ & Initial TFP in manufacturing & 2.265 \\
$A_{M, 0}$ & Rate of technological progress & $0.1 \%$ \\
$\gamma_{A}$ & Birth rate at $w=\underline{c}$ & $2.75 \%$ \\
$\underline{b}$ & Death rate at $w=\underline{c}$ & $3.02 \%$ \\
$\underline{d}$ & Elasticity of birth rates wrt. income & 1.41 \\
$\varphi_{b}$ & Elasticity of death rates wrt. income & -0.55 \\
$\varphi_{d}$ & City excess mortality & 0.5 \\
$k_{M} / k_{B}-1$ & Maximum trade and war effect & 0.333 \\
$\bar{h}_{M}$ & Tax rate on above-subsistence income & 0.52 \\
$\tau$ & Fixed cost of warfare (relative to population) & 0.011 \\
$f_{W}$ & Belligerence parameter for Europe & 22.54 \\
$A_{W}$ & Belligerence parameter for China & 5.63 \\
$A_{W}^{\text {China }}$ & Upper bound on city growth (after pre-plague & $0.46 \%$ \\
$\bar{v}$ & urban housing stock is re-occupied) & \\
& Population & 1.0 \\
Resulting values in the pre-plague steady state $E_{0}$ & $2.5 \%$ \\
$N_{0}$ & Urbanization rate & $3.0 \%$ \\
$n_{M, 0}$ & Economy-average birth and death rate & 1.0 \\
$b_{0}=d_{0}$ & Relative price of manufacturing goods & \\
$p_{M, 0}$ &
\end{tabular}

the difference between the two regions-when counting individual battles instead of the number of conflicts, the ratio is as low as 0.02, reflecting 23 major battles in China between 1400 and 1800 vs. 1,071 in Europe Jaques, 2007). Table 1 summarizes the calibrated parameters.

\subsection{Steady states with strong "Horsemen Effect": Europe}

Using the calibrated parameters for Europe, the left panel of Figure 6 shows two stable steady states, $E_{0}$ and $E_{H}$, and an unstable one, $E_{U}$. Initially, the European economy is in $E_{0}$, and all variables remain unchanged in the absence of technological progress. In order to initiate the transition from $E_{0}$ to $E_{H}$, a shock to population (or productivity) must be large enough to push the economy beyond $E_{U}$, where Horsemen-augmented death rates exceed birth rates 59 We argue that early modern Europe underwent such a transition. Following the Black Death, p.c. incomes surged. The demand for urban goods made cities grow, fostering trade and providing the means for warfare. Enhanced mobility spread epidemics and raised mortality. Driven by this "Horsemen effect", the economy converges to point $E_{H}$ in Figure 6 This steady state is characterized by higher birth and death rates (about 3.8\%) and higher urbanization (8.2\%). The corresponding dynamics are shown in the right panel of Figure6 The Black Death kills $40 \%$ of the population. Immediately after this, the urbanization rate rises steeply until the pre-plague urban housing stock is re-occupied. Thereafter, the constraint on migration becomes binding so that the urbanization

59. With ongoing technological progress the argument is similar. Continuous technological progress implies rising population at stagnant p.c. income. We analyse this case later. 

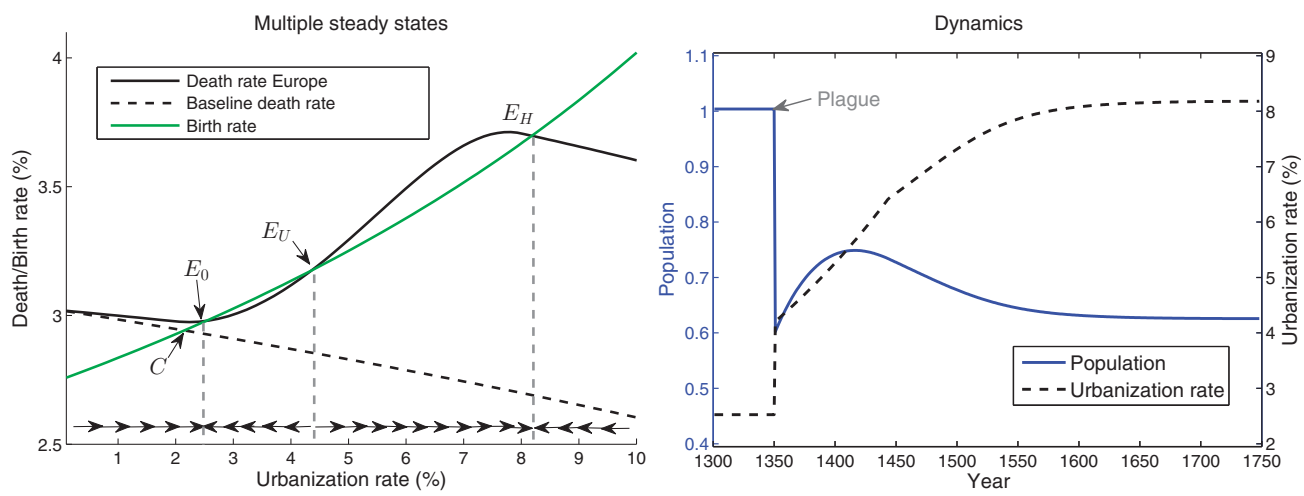

FIGURE 6

Long-run impact of the plague with "Horsemen effect"-The case of Europe

rate increases more slowly (until about 1450 in the simulation), and eventually converges to its new steady state.

Urbanization, trade, and war increased per capita incomes in early modern Europe. As by our calibration, their individual contributions to aggregate death rates in $E_{H}$ are approximately $0.15 \%$, $0.25 \%$, and $0.75 \%$, respectively. This corresponds to the 17 th century, when the "Horsemen effect" reached its maximum. Given the slope of the birth schedule, we can translate the increasing death rates into the corresponding changes in urbanization. City mortality alone would have raised urbanization by over $1 \%$. The effect of trade is similar, but slightly larger. The single biggest contributor, according to our baseline calibration, is war. It alone raises urbanization rates by approximately $4 \%$. In combination, the Horsemen can account for an increase in the percentage of Europeans living in towns and cities from $2.2 \%$ in $C$ to approximately $8 \%$ in $E_{H} 60$ Using the relationship depicted in Figure 5 we can translate those urbanization rates into p.c. income levels. The $2.2 \%$ in $C$ correspond to a p.c. income of 1.08 (where 1.0 is subsistence), which grows to 1.34 in $E_{H}$. The resulting increase in p.c. income of approximately $25 \%$ is very similar to the number provided by Maddison 2007) for Western European growth between 1500 and 1700: $30 \% 61$

Our story can explain rising urbanization and individual income in early modern Europe in the absence of technological change. However, in this reduced form our model predicts falling population, which contradicts the observed trend. Next, we allow for slowly growing productivity.

\subsection{The role of technological progress}

Technological progress in pre-modern times alone is not enough to escape from the Malthusian trap. While a growing population eventually reverses the benefits of one-time inventions, ongoing progress implies higher, but still stagnating, steady state p.c. income. Its effects are thus similar to a permanent outward shift of the death schedule. The new steady state can be derived from Equation (3). Constant p.c. income (and thus a constant agricultural labour share) implies $\gamma_{N}=\gamma_{A} /(1-\beta)$, with $\gamma_{A}$ representing total factor productivity (TFP) growth. Thus, steady state population growth is proportional to the rate of technological progress.

60. Point $C$ reflects the steady state for baseline mortality only.

61. Maddison does not report income figures for 1300. Interpolating the estimates for 1000 and 1500 to obtain a proxy for 1300 implies p.c. income growth of approximately 50\% between 1300 and 1700 . 

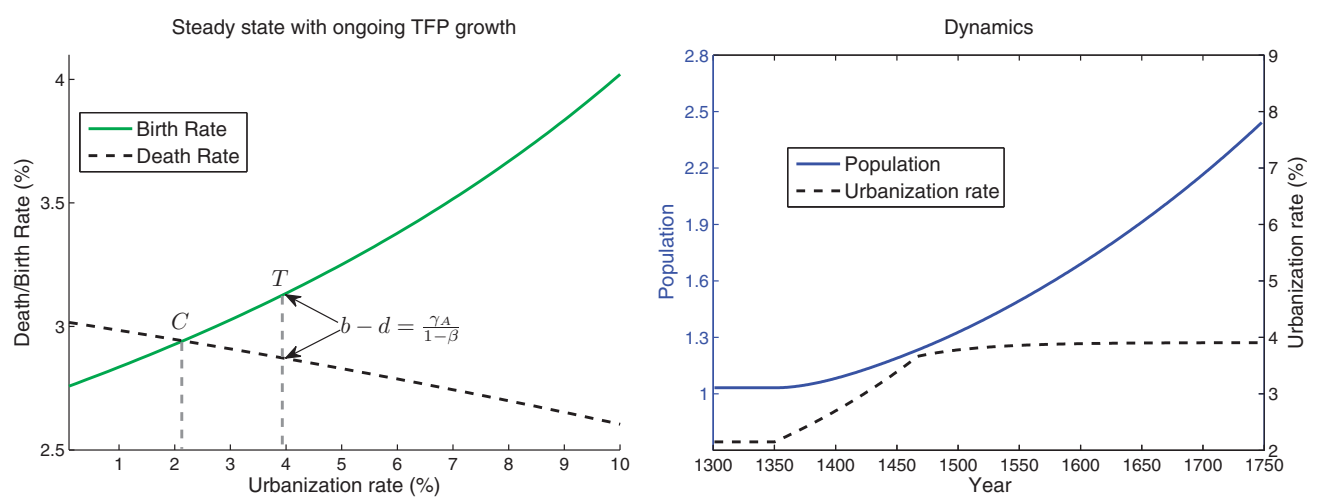

FIGURE 7

Effect of ongoing technological progress

The setup with ongoing technological progress corresponds to a steady state in point $T$ in the left panel of Figure 7 where the birth rate exceeds the death rate and technological progress offsets the falling land-labour ratio. The right panel of Figure 7 illustrates the orders of magnitude involved. The rate of technological change before the Industrial Revolution was low, approximately $0.1 \%$ Galon, 2005). For purposes of illustration, we begin in 1300. Progress is assumed to set in after 50 years of stagnating technology. As the figure shows, this raises the urbanization rate by less than $2 \%$. This is an extreme scenario where the economy jumps from complete stagnation to continuous inventions. The corresponding increase of urbanization is thus an upper bound for the impact of technology on individual income. Our calibrated model therefore suggests that the effect of technological progress in early modern Europe was markedly smaller than the impact of rising death rates.

How fast would technology have to improve to explain the rise of early modern Europe? Based on Maddison's 2007) figures we derive a lower bound, focusing on the period 1500-1700. Over these two centuries, European p.c. income increased by 30\%. If technological improvements were the sole cause for this rise, the rate of population growth in 1700 would be at least $1.7 \% 62$ To sustain per capita incomes at 30\% above the 1500 level, technological progress would have to offset the rapid population growth, which implies TFP growth rates of $\gamma_{A}=(1-\beta) \gamma_{N} \simeq 0.7 \%$. TFP increases of this magnitude were not observed before the second half of the 19th century Crafts and Harley, 1992; Antràs and Voth, 2003). If we assessed the strength of Malthusian responses accurately, technological progress cannot be a candidate to explain the "Rise of Europe" in the early modern period.

\subsection{Model fit}

How well does our model fit the data? We begin simulations in 1000 AD to show both the pre- and post-plague fit of the model 63 While the "Horsemen effect" by itself can account for

62. To derive this number, we normalize p.c. income to unity in $1500, y^{1500}=1$, and set $b_{0}=d_{0}=3 \%$. Together with 8 and 17 this setup implies $\gamma_{N}^{1500}=0$. We then use a linear approximation to derive the population growth rate, $\gamma_{N}^{1700}$, corresponding to the higher level of p.c. income in 1700 . This yields $\gamma_{N}^{1700}=\left(\varphi_{b}-\varphi_{d}\right) b_{0}\left(y^{1700}-y^{1500}\right)=$ $(1.41+0.5) \cdot 3 \% \cdot 0.3=1.72 \%$.

63. We allow technology to grow at $\gamma_{A}=0.1 \%$ throughout the simulation. This is in line with the estimates by Galor 2005 ) of roughly $0.05-0.15 \%$ per year. The model is calibrated to yield the same pre-plague (1350) values as above for 

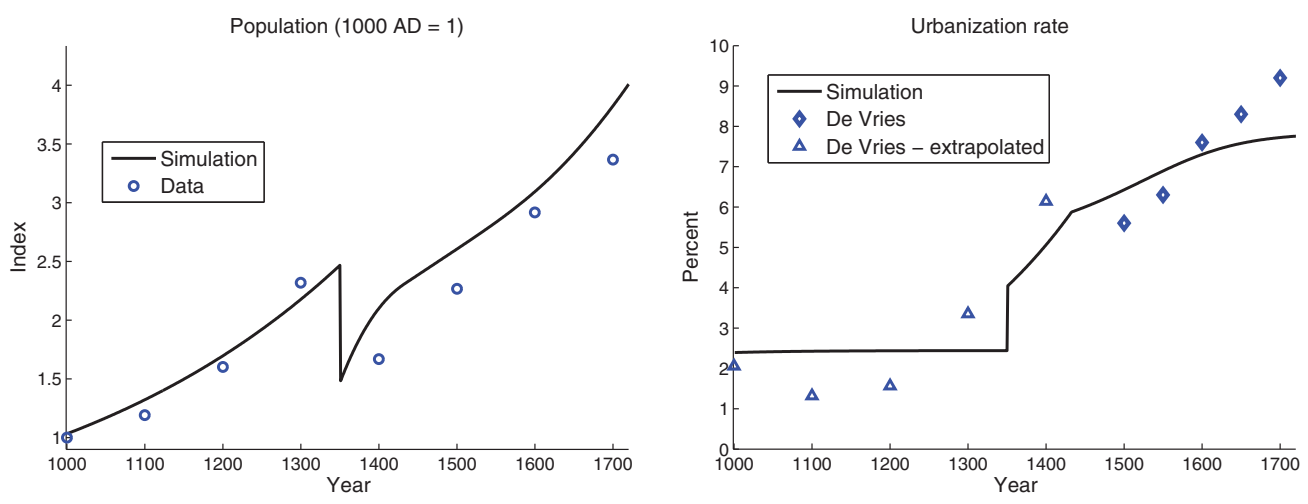

FIGURE 8

Europe: simulation results vs. data. Sources: population for Europe (exclusive of the Balkans and Russia) from McEvedy and Jones 1978). Urbanization rates: For 1500-1700 from de Vries 1984); 1000-1400: De Vries 1984, extrapolated using data from Bairoch et al. 1988). See the notes below Figure 4 and Appendix A.1 for details

much of the observed increase in European urbanization (see Figure 6), technological progress is responsible for the growth in population. In other words, technological progress alone, without the Horsemen, translates into rapid population increases, while per capita income stagnates. On the other hand, the Horsemen alone, without TFP growth, deliver higher per capita income (Figure 6, but aggregate income decreases because of the substantial population decline. Both mechanisms together deliver growing population and per capita income, and therefore also rising aggregate income 64 A simple calculation sheds light on the relative importance of the two components. Using Maddison's 2007) numbers for Europe in 1500 and 1700, we find that rising per capita income accounts for $42 \%$ of aggregate GDP increases over this period, and population growth explains the remaining 58\% 65 Finally, Figure 8 shows our simulation results together with the data. Our model performs well in reproducing both population growth and urbanization 6

4.4.1. Implications for relative prices. Our model has implications for the relative price of urban vs. rural goods. First, as the plague raises wages, the price of goods produced in cities should rise relative to those produced in the countryside. The reason is that richer consumers want to buy more of the highly income-elastic goods produced in towns. Cities cannot grow at infinite speed because of the need to build urban infrastructure (reflected by the parameter $\bar{v}$ in our model). This bottleneck means that higher demand translates into higher relative prices after the plague. As migration to cities continues, growing supply of urban goods leads to declining relative prices. This effect is reinforced by declining demand: with population slowly recovering,

population, urbanization, fertility, mortality, and relative prices (as given in the lower part of Table 1 . Intuitively, this technology-progress-adjusted calibration corresponds to shifting the death schedule downwards by $\gamma_{A} /(1-\beta)$ in Figure 7 The new steady state with ongoing technological progress (but lower mortality) then involves the same urbanization rate as the previous $C$ in the figure.

64. In our calibration, the rate of TFP growth $\gamma_{A}=0.1 \%$ is sufficiently large for productivity-driven population increases to overcompensate population losses due to the Horsemen.

65. Aggregate European GDP grew at rate of $0.31 \%$ p.a. between 1500 and 1700, with p.c. income and population growing at 0.13 and $0.18 \%$, respectively.

66. Note that urbanization rates spike immediately after the Black Death because the empty urban housing stock is reoccupied. Thereafter, the city growth constraint $\bar{v}$ is binding, and urbanization rises more slowly. From about 1450 onward, the constraint is not binding anymore as the model predicts fewer migrants moving to cities. 


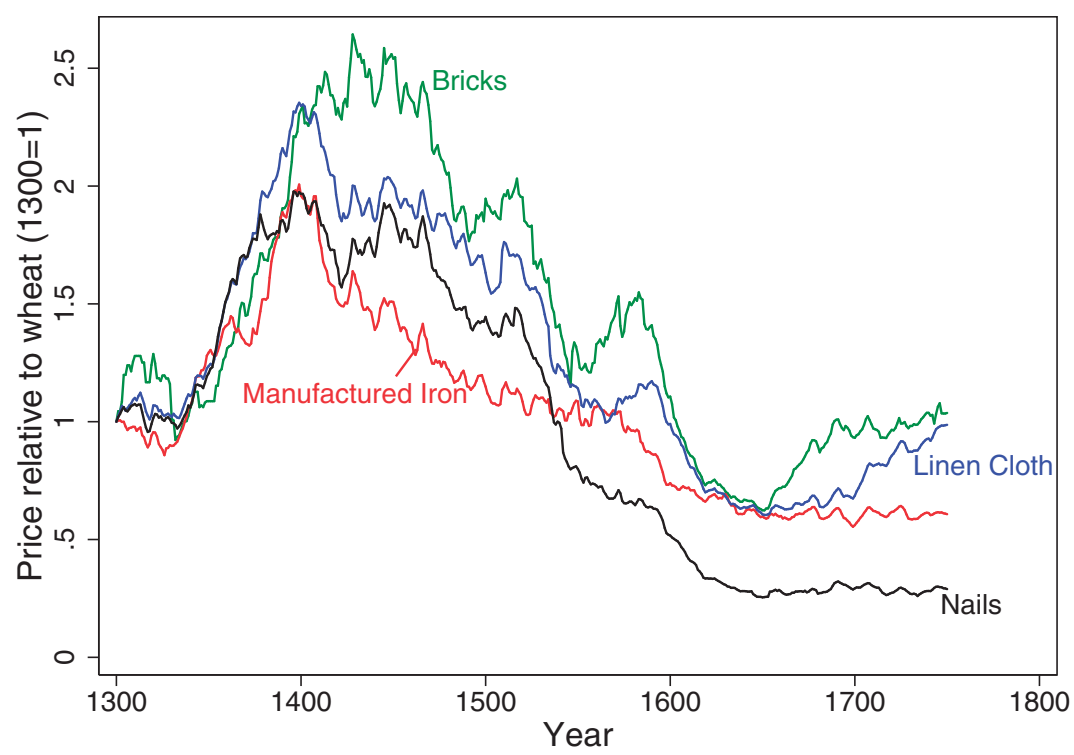

FIGURE 9

Prices of manufactured goods relative to wheat for England, 1300-1750. Notes: Price data from Clark 2005). All prices are relative to the price of wheat; the 25 -year moving average is depicted

p.c. income falls. Our model thus predicts a hump-shaped pattern for the relative price of urban goods during the aftermath of the Black Death.

We investigate this prediction by analysing the price data collected by Clark 2005) 67 His database contains retail prices for numerous manufactured goods, most of which are typical "urban" products. Figure 9 plots the price of four manufactured goods, relative to the price of wheat, for the period 1300-1750. All four goods-bricks, manufactured goods made of iron, nails, and linen-show strong price increases immediately after the Black Death. Relative prices peaked 50-80 years after the plague. This seems a sensible time horizon over which the immediate disruptions of production (which we do not model) could dissipate. Eventually, during the $15^{\text {th }}$ century, urban infrastructure could catch up with demand, and migration into the towns raised the supply of urban goods. This explains the falling relative price of urban goods after 1400. What is crucial for testing our model is that in the medium run-following the impact of the Black Death, the relative price of manufactured goods increases. This confirms our use of Engel curves to predict higher demand for urban products after the plague.

\subsection{Plague and steady state with weak "Horsemen Effect": China}

Next, we present simulation results for China, which was less belligerent than Europe and did not experience urban excess mortality. Thus, the "Horsemen effect" is substantially smaller in China-mortality rises only modestly with urbanization, so that the Chinese economy resembles the left panel of Figure $1{ }^{68}$ The economy is trapped in Malthusian stagnation in a unique steady state $C$. The fertility and mortality schedules intersect at approximately $3 \%$, while $2.2 \%$ of the

67. We thank Gregory Clark for sharing this data with us.

68. The exact calibrated schedules for China are shown in Appendix A.6. 
REVIEW OF ECONOMIC STUDIES

TABLE 2

Urbanization and its contribution to average mortality

\begin{tabular}{lccccc}
\hline & & Europe & NL & Italy & England \\
\hline Year & & \multicolumn{4}{c}{ Urbanization } \\
1300 & & 3.4 & 6.4 & 10.6 & 2.2 \\
1700 & & 9.2 & 33.6 & 13.2 & 13.3 \\
& & \multicolumn{4}{c}{ Mortality } \\
& City penalty & to $n_{M}(\%)$ & \\
1300 & $\triangle d_{M}=50 \%$ & 0.05 & 0.10 & 0.16 & 0.03 \\
1300 & $\triangle d_{M}=80 \%$ & 0.08 & 0.15 & 0.25 & 0.05 \\
1700 & $\triangle d_{M}=50 \%$ & 0.14 & 0.50 & 0.20 & 0.20 \\
1700 & $\triangle d_{M}=80 \%$ & 0.22 & 0.81 & 0.32 & 0.32 \\
\hline
\end{tabular}

Sources: Urbanization rates in 1700 from De Vries 1984); in 1300 extrapolating de Vries figures backwards with the country-specific trend based on Bairoch et al. 1988). See Appendix A.1 for details. The table shows the country-wide additional mortality due to city excess mortality $\left(\triangle d_{M}\right)$, calculated as $\triangle d_{M} \cdot n_{M}$.

population live in cities. The latter corresponds to wages that exceed subsistence by $8 \%$. The Black Death in China has a transitory effect (see Appendix A.6 for a graphical illustration). Before the plague, population, and urbanization stagnate. We assume that - as in Europe-the Black Death reduces population by $40 \%$. As an immediate consequence, wages and p.c. consumption rise. Urbanization rates initially spike as empty urban housing stock is quickly re-occupied. From then on, urbanization increases more slowly because the migration constraint binds. In the aftermath of the plague, population grows because the economy is now situated to the right of the steady state in point $C$, with fertility higher than mortality. The falling land-labour ratio eventually drives the economy back to $C$, with all variables returning to their pre-plague values.

\subsection{Robustness of calibration results}

Next, we examine the robustness of our calibration results when alternative parameter values are used. The size of the "Horsemen effect" is central to our results. To shed light on the margin of error of the overall effect, we discuss the contribution of individual components. Data on excess city mortality are relatively reliable. Table 2 shows the corresponding magnitudes in 1300 and 1700 for various countries and two different city mortality penalties-one corresponding to our baseline calibration and the other representing an upper bound, $80 \%$. The upper bound is derived from the ratio of Northern town mortality and the rural Sussex death rate in 1841 Szreter and Mooney, 1998). Clark and Cummins 2009) find a similar differential between the offspring of urban and rural testators in early modern England 69 From one country to the next, the magnitude of the direct "Horsemen effect" varies substantially depending on overall urbanization rates. In England it is initially close to zero. As urban centers grow, it increases to $0.2-0.32 \%$. In the most urbanized countries in Europe, such as the Netherlands, the direct effect reaches $0.5-0.8 \%$. On average in Europe, city mortality contributed 0.05 to $0.22 \%$ to overall death rates. With the value from our baseline calibration, $0.14 \%$, this factor alone can account for $1.2 \%$ higher urbanization rates, or one-fifth of the total.

Next, we turn to the indirect "Horsemen effect" due to warfare and trade. In Section 4.1 we argued that war-related deaths added $0.5-1.0 \%$, based on the war frequency in the second half of

69. The life expectancy at birth on farms in their sample is 41.8 ; in cities and towns, it falls from 32 to 29 . The latter is derived from the weighted average of London mortality and that in other urban centers. 
the 17th century. For trade we base our estimate of $0.25 \%$ on an analogy with the trade and HIV in modern-day Africa Oster, 2009). Even if we use the lower bound of the warfare effect $(0.5 \%)$, and assume zero for trade, the "Horsemen" play a substantial role. Under these conservative assumptions, the two remaining effects (city death and warfare) raise urbanization rates to about 6\% (Appendix A.7).

The responsiveness of population growth to p.c. income changes is important for our findings. This variable is governed by the elasticity of birth and death rates to nutrition, based on Kelly's 2005 estimates for early modern Britain. More recent work by Kelly and Ó Grada 2008 confirms the orders of magnitude involved. If the $b$ and $d$ schedules are flatter than in our baseline calibration, population growth reacts more slowly to income increases. Consequently, there is more scope for technological progress to improve living standards. On the other hand, the model also becomes more sensitive to an increase in background mortality, which increases the power of the Horsemen. More precisely, if both $b$ and $d$ have only half the slope that we used in the baseline calibration, technological progress at $0.1 \%$ p.a. delivers a $4 \%$ increase in urbanization (corresponding to roughly $9 \%$ increase in p.c. income) 70 This leaves ample scope for the "Horsemen of Riches" to contribute to the "Rise of Europe".

Our calibration implicitly determines the minimum size of the "Horsemen effect" that is required to generate multiple steady states, i.e. to have a long-run effect. For this to be the case, the birth and death schedule must cross more than once. In Figure 6 the "Horsemen effect" has to account for at least the mortality differential between $E_{U}$ and $C$-approximately $0.25 \%$. Our lower-bound estimate for the war-related "Horsemen" alone is almost double in size (see Section 4.1). Mortality changes were thus large enough for our model to capture important aspects of the historical experience in early modern Europe. China, on the other hand, has only one Malthusian steady state even if we increase its belligerence parameter to half of its European counterpart. This is because lower belligerence implies a flatter slope of the "Horsemen effect", so that the death schedule does not cross the birth schedule from below (see Appendix A.7 for the corresponding graph).

Finally, we include two extensions of our model in the Appendix. First, in Appendix A.8 we allow for negative effects of warfare on productivity, reflecting the destruction of physical capital, slaughter of livestock, and the disruption of communications during early modern military campaigns. While dynamics in the short run change, our long-run results are robust to this extension. Second, Appendix A.9 introduces the effect of the European Marriage Pattern (EMP) into our setup with multiple Malthusian steady states. EMP alleviated population pressure by reducing birth rates - an effect that was particularly strong in North-Western Europe. Elsewhere, we argue that EMP contributed importantly to intra-European divergence Voigtländer and Voth, 2009, 2011). In the case of England, where income surged ahead of other European countries after 1500, the "Horsemen effect" alone accounts for approximately one half of the rise in wages and urbanization. EMP can explain much of the remainder.

\section{CONCLUSION}

Europe saw almost continuous warfare during the early modern period. It also suffered numerous disease outbreaks. Its cities were major death traps. Far from undermining the strength of the European economy, we argue that death and disease spelled riches and power, contributing to Europe's economic ascendancy. We use a simple two-sector Malthusian model in which higher

70. To derive this result, we follow the approximation shown in footnote 62 using the fact that population must grow at $\gamma_{N}=\gamma_{A} /(1-\beta)$ in steady state. 
population lowers incomes because of declining marginal returns to labour. The Black Death killed between a third and half of the European population. In a Malthusian setting, a boost to incomes after an epidemic should be transitory. Yet the plague shock was so big that several generations of population growth would have been necessary to reverse the substantial wage gains. In the meantime, political and structural changes effectively produced a ratchet effect. Europe's "golden age of labour" after 1350 saw a richer population buying more manufactured goods, produced to a large extent in urban centers. Because early modern European cities were "graveyards" Bairoch, 1991), this boost to urbanization rates reduced pressure on land-labour ratios, helping to stabilize incomes. The plague shock also perpetuated higher incomes through two other channels. Higher incomes meant that there was more money available for taxation and borrowing. Thus princes fought more often, and for longer. Higher incomes also stimulated trade, which spread disease. These repercussions of the Black Death acted as "Horsemen of Riches" because they jointly increased mortality, preserving post-plague wage gains.

Permanently higher mortality rates, indirectly caused by the Black Death, were quantitatively important. In our calibrations, the mortality channel alone can account for at least half of the increase in per capita incomes in early modern Europe. Of this increase, the largest component came from more frequent warfare. Diseases spread by trade and excess city mortality made smaller contributions.

Non-reproducible factors of production, such as land, still play a role in production in today's Third World Weil and Wilde, 2009). That is why deadly epidemics such as AIDS may raise per capita incomes (Young, 2005). Osten 2009) shows that HIV in Africa spreads along trade routes. Since trade is linked to incomes, a similar feedback mechanism to the one we identified in early modern Europe may operate in developing countries. Urbanization and war, on the other hand, are unlikely to have similar effects. Military technology has become markedly more destructive. In addition, cities are no longer notably less healthy than rural areas.

Why did war, disease, and urbanization not yield similar results outside Europe in pre-modern times? Neither plagues, war, nor cities were unique to Europe. However, European cities were remarkably unhealthy, for a variety of cultural reasons. A highly fragmented political environment gave rise to frequent wars. The absence of these factors limited the operation of the "ratchet effect" elsewhere. The plague in China could not produce a similar, self-reinforcing cycle of higher incomes and rising mortality. There, a one-off increase in wages did not produce a lasting rise in death rates. Similarly, the Justinian Plague that hit Imperial Rome-possibly just as devastating at its 14 th-century counterpart—occurred at a time when Roman cities were amply provided with clean water. They were also not as overcrowded as early modern European cities. The latter kept concentrating ever larger numbers of people in the same area, protected by massive fortifications. In 14th-century China and in Justinian Rome, another crucial "Horseman of Riches"-war-was also not available. Both regions were politically unified, and a rise in city wealth did not translate into more frequent warfare 71

Economic fortunes diverged markedly within Europe during the early modern period. North-Western Europe pulled decisively ahead of other areas, such as the Mediterranean Acemoglu et al., 2005). While we do not explore this aspect in detail, the differential impact of the plague also appears to be a good predictor of changes in urbanization. Figure 10 plots the increase in the share of urban population against the population losses as a result of the Black Death. Where the plague shock was largest, subsequent gains in urbanization were strongest. Also,

71. Political fragmentation was also much lower in the Middle East, which was hard-hit by the 14th century plague. Much of it was quickly unified under first the Mamluks, then the Ottomans. This limited the potential for death rates to be driven up by continued fighting. In addition, the destruction of irrigation systems in the Middle East by the Mongols did much to undermine production. Europe did not have similarly centralized, vulnerable infrastructure. 

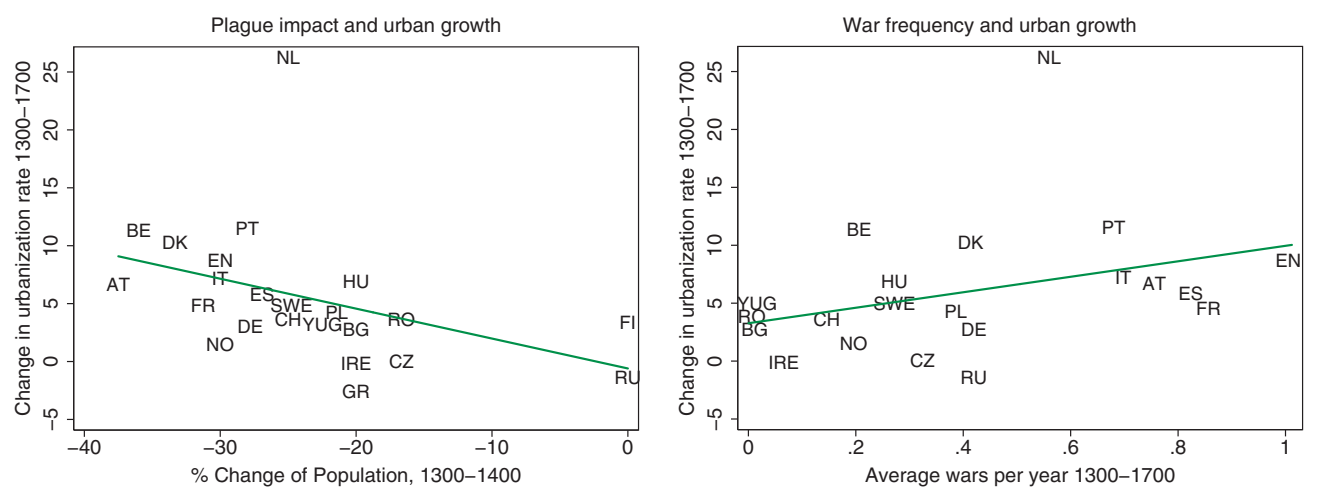

FIGURE 10

Population losses during the Great Plague, warfare, and early modern urbanization. Notes: population change 1300-1400 from McEvedy and Jones 1978), combined with information on the impact of the plague in Benedictow 2004). Change in urbanization from Bairoch et al. 1988), as explained in Appendix A.1. Average wars per year are derived from the dataset used in Acemoglu et al. 2005). Left panel: the regression line has a slope parameter of -0.258 with a $t$-statistic of -3.71 (robust standard errors) and an $R^{2}$ of 0.17 . When excluding the outlier Netherlands, the slope becomes -.243 ( $t$-statistic -3.33$)$, while the fit improves $\left(R^{2}\right.$ of 0.37$)$. Finally, when we additionally exclude the zero-population change observations Finland and Russia, both fit and significance increase (slope $-0.394, t$-statistic $\left.-3.72, R^{2} 0.42\right)$. Right panel: the regression line has a slope of 6.68 with a $t$-statistic of 2.59 (robust standard errors) and an $R^{2}$ of 0.12 . When excluding the outlier Netherlands, the slope parameter is 4.96 ( $t$-statistic 3.04 and $R^{2} 0.17$ ).

there is some evidence that areas that were affected the most by war saw the biggest increases in the share of the population living in cities.

Our article emphasizes the paradoxical increase of incomes in early modern Europe. Europe's political fragmentation and geographical heterogeneity interacted with the negative shock of the Black Death in a unique way. In combination, urbanization, warfare, and trade produced a mortality regime that was different from the one prevailing in other parts of the world. As a result, death and disease contributed importantly to the "Rise of Europe".

Acknowledgments. We would like to thank the editor, Kjetil Storesletten, and five anonymous referees, as well as Steve Broadberry, Greg Clark, Nick Crafts, Angus Deaton, Matthias Doepke, Oded Galor, Avner Greif, Bob Hall, Nobu Kiyotaki, Ephraim Kleiman, Kiminori Matsuyama, Omer Moav, Joel Mokyr, Rachel Ngai, Ron Lee, Ed Prescott, Diego Puga, Michèle Tertilt, Karine van der Beek, Jaume Ventura, David Weil, and Fabrizio Zilibotti for helpful comments and suggestions. Seminar audiences at Ben Gurion, Brown University, Hebrew University, Humboldt University, the Minnesota Macro Workshop, Northwestern University, Pompeu Fabra, UC Berkeley, UCLA, Princeton, and Zürich University offered helpful advice. Morgan Kelly shared unpublished results; Mrdjan Mladjan provided outstanding research assistance. Financial support by the European Research Council (ERC), and the Barcelona GSE is gratefully acknowledged.

\section{REFERENCES}

ACEMOGLU, D., JOHNSON, S. and ROBINSON, J. A. (2005), “The Rise of Europe: Atlantic Trade, Institutional Change and Economic Growth", American Economic Review, 95, 546-579. ALLEN, R. C. (2001), "The Great Divergence in European Wages and Prices from the Middle Ages to the First World War", Explorations in Economic History, 411-447, 38.

ALLEN, R. C. (2009), "Agricultural Productivity and Rural Incomes in England and the Yangtze Delta, c. 1620-c.1820”, Economic History Review, 62, 525-550.

ANDERSON, M. and LEE, R. (2002), "Malthus in State Space: Macro Economic-demographic Relations in English History, 1540 to 1870", Journal of Population Economics, 15, 195-220. 
ANTRÀS, P. and VOTH, H.-J. (2003), "Factor Prices and Productivity Growth during the British Industrial Revolution", Explorations in Economic History, 38, 52-77.

ASHRAF, Q. and GALOR, O. (2011), "Dynamics and Stagnation in the Malthusian Epoch", American Economic Review, 101, 2003-2041.

BAIROCH, P. (1991), Cities and Economic Development from the Dawn of History to the Present (Chicago: University of Chicago Press).

BAIROCH, P., BATOU, J. and CHÈVRE, P. (1988), La Population des villes Europeenees de 800 à 1850: Banque de Données et Analyse Sommaire des Résultats. Centre d'histoire economique Internationale de l'Université de Genève, Libraire Droz, Geneva.

BEAN, R. (1973), "War and the Birth of the Nation-State", Journal of Economic History, 33, 203-221.

BENEDICTOW, O. J. (2004), The Black Death 1346-1353. The Complete History (Woodbridge: The Boydel Press).

BERGSTRAND, J. H. (1985), “The Gravity Equation in International Trade: Some Microeconomic Foundations and Empirical Evidence", The Review of Economics and Statistics, 67, 474-481.

BIRABEN, J.-N. (1975), Les hommes et la peste en France et dans les pays européens et méditerranéens (Paris · La Haye: Mouton).

BLANCHARD, O. J. (1985), "Debt, Deficits and Finite Horizons", Journal of Political Economy, 93, 223-247.

BOSKER, M., BURINGH, E. and VAN ZANDEN, J. L. (2008), From Baghdad to London: The Dynamics of Urban Growth in Europe and the Arab World, 800-1800.

BOSWORTH, B. P. and COLLINS, S. M. (2003), "The Empirics of Growth: An Update", Brookings Papers on Economic Activity, 34, 113-206.

BRAINERD, E. and SIEGLER, M. (2003), "The Economic Effects of the 1918 Influenza Epidemic”. (CEPR Discussion Papers, (3791)).

BRAUER, F. and CASTILLO-CHÁVEZ, C. (2001), Mathematical Models in Population Biology and Epidemiology (NY: Springer).

BROADBERRY, S., CAMPBELL, B. M. S. and VAN LEEUWEN, B. (2011), “Arable Acreage in England, 1270-1871". (Working Paper).

BROADBERRY, S. and GUPTA, B. (2006), "The Early Modern Great Divergence: Wages, Prices and Economic Development in Europe and Asia, 1500-1800", Economic History Review, 59, 2-31.

BURINGH, E. and van ZANDEN, J. L. (2009), "Charting the "Rise of the West": Manuscripts and Printed Books in Europe, A Long-Term Perspective from the Sixth through Eighteenth Centuries", Journal of Economic History, 69, 409-445.

CERVELLATI, M. and SUNDE, U. (2005), "Human Capital Formation, Life Expectancy, and the Process of Development", American Economic Review, 95, 1653-1672.

CHOW, G. C. and LIN, A. (1971), "Best Linear Unbiased Interpolation, Distribution, and Extrapolation of Time Series by Related Series", Review of Economics and Statistics, 53, 372-375.

CLARK, G. (2005), "The Condition of the Working Class in England, 1209-2003”, Journal of Political Economy, 113, 1307-1340.

CLARK, G. (2007), A Farewell to Alms: A Brief Economic History of the World (Princeton: Princeton University Press).

CLARK, G. and CUMMINS, N. (2009), "Urbanization, Mortality and Fertility in Malthusian England", American Economic Review, Papers and Proceedings, 99, 242-247.

COLEMAN, D. C. (1983), "Proto-Industrialization: A Concept Too Many", Economic History Review, 36, 435-448. 
COLLIER, P. and HOEFFLER, A. (1998), "On Economic Causes of Civil War”, Oxford Economic Papers, 50, 563-573.

COLLIER, P. AND HOEFFLER, A. (2004), "Greed and Grievance in Civil War", Oxford Economic Papers, 56, 563-595.

COMIN, D., EASTERLY, W. and GONG, E. (2010), "Was the Wealth of Nations Determined in 1000 BC?", American Economic Journal: Macroeconomics, 2, 65-97.

CRAFTS, N. F. R. (1985), British Economic Growth During the Industrial Revolution (Oxford: Oxford University Press).

CRAFTS, N. F. R. and HARLEY, K. (1992), "Output Growth and the British Industrial Revolution: A Restatement of the Crafts-Harley View”, Economic History Review, 45, 703-730.

CRAFTS, N. F. R. and MILLS, T. (2008). "From Malthus to Solow: How the Malthusian Economy Really Evolved", Journal of Macroeconomics (forthcoming).

de VRIES, J. (1976), The Economy of Europe in an Age of Crisis (Cambridge: Cambridge University Press).

de VRIES, J. (1984), European Urbanization 1500-1800 (London: Methuen and Co Ltd.).

DESMET, K. and PARENTE, S. L. (2009), "The Evolution of Markets and the Revolution of Industry: A Quantitative Model of England's Development, 1300-2000”. (Mimeo, Universidad Carlos III).

DIAMOND, J. (1997), Guns, Germs, and Steel: The Fates of Human Society (New York: Norton).

DYER, C. (1988), "Changes in Diet in the Late Middle Ages: The Case of Harvest Workers", Agricultural History Review, 36, 21-37.

ELVIN, M. (1973), The Pattern of the Chinese Past. (Stanford: Stanford University Press).

ENGERMAN, S. (1972), "The Slave Trade and British Capital Formation in the Eighteenth Century", Business History Review, 46, 430-443.

GALLEY, C. (1998), The Demography of Early Modern Towns: York in the Sixteenth and Seventeenth Centuries. (Liverpool: Liverpool University Press).

GALLOWAY, P. R. (1988), "Basic Patterns in Annual Variations in Fertility, Nuptiality, Mortality, and Prices in Pre-industrial Europe", Population Studies, 42, 275-302.

GALOR, O. (2005), "From Stagnation to Growth: Unified Growth Theory", in Aghion, P. and Durlauf, S. (eds) Handbook of Economic Growth, Vol. 1, Chapter 4, (Elsevier), 171-293.

GALOR, O. and MOAV, O. (2002), "Natural Selection and the Origin of Economic Growth", Quarterly Journal of Economics, 117, 1133-1191.

GALOR, O. and WEIL, D. N. (2000), "Population, Technology and Growth: From the Malthusian Regime to the Demographic Transition and Beyond", American Economic Review, 90, 806828.

GROSSMAN, H. (1991), “A General Equilibrium Model of Insurrections”, American Economic Review, 81, 912-921.

HANLEY, S. B. (1997), Everyday Things in Premodern Japan: The Hidden Legacy of Material Culture. (Berkeley: University of California Press).

HANSEN, G. and PRESCOTT, E. (2002), "Malthus to Solow", American Economic Review, 92, $1205-1217$.

HAYAMI, A. (2001), The Historical Demography of Pre-Modem Japan (Tokyo: University of Tokyo Press).

HAZAN, M. (2009), "Longevity and Lifetime Labor Supply: Evidence and Implications", Econometrica, 77, 1829-1863.

HERLIHY, D. (1997), The Black Death and the Transformation of the West (Cambridge, MA: Harvard University Press).

HOEFFLER, A. and REYNAL-QUEROL, M. (2003), "Measuring the Costs of Conflict” (Oxford University working paper). 
HORRELL, S. (1996), "Home Demand and Industrialization", Journal of Economic History, 56, 561-604.

JAQUES, T. (2007), Dictionary of Battles and Sieges: A Guide to 8,500 Battles from Antiquity through the 21st Century (Greenwood Press).

JONES, C. I. (2001), "Was an Industrial Revolution Inevitable? Economic Growth Over the Very Long Run", Advances in Macroeconomics, 1, 1-45. Article 1.

JONES, E. L. (1981), The European Miracle: Environments, Economies, and Geopolitics in the History of Europe and Asia (New York: Cambridge University Press).

KALEMLI-OZCAN, S. (2002), "Does Mortality Decline Promote Economic Growth?”, Journal of Economic Growth, 7, 411-439.

KARAMAN, K. and PAMUK, S. (2010), "Ottoman State Finances in European Perspective, 1500-1914”, Journal of Economic History, 70, 593-629.

KELLY, M. (2005), "Living Standards and Population Growth: Malthus was Right", (UC Dublin working paper).

KELLY, M. and Ó GRADA, C. (2008), "The Poor Law versus the Positive Check: Living Standards and Mortality in England since the Middle Ages", (UC Dublin working paper).

KERMACK, W. O. and MCKENDRICK, A. G. (1927), "A Contribution to the Mathematical Theory of Epidemics", in Proceedings of the Royal Society of London, Vol. 115 of A, pp. 700-721.

KREMER, M. (1993), "Population Growth and Technological Change: One Million B.C. to 1990”, Quarterly Journal of Economics, 108, 681-716.

LAGERLÖF, N.-P. (2003), "From Malthus to Modern Growth: Can Epidemics Explain the Three Regimes?", International Economic Review, 44, 755-777.

LAGERLÖF, N.-P. (2010), "From Malthusian War to Solovian Peace", Review of Economic Dynamics, 13, 616-636.

LANDERS, J. (1993), Death and the Metropolis: Studies in the Demographic History of London, 1670-1830 (New York: Cambridge University Press).

LANDERS, J. (2003), The Field and the Forge: Population, Production, and Power in the PreIndustrial West (New York: Oxford University Press).

LEE, J. AND FENG, W. (1999), "Malthusian Models and Chinese Realities: The Chinese Demographic System 1700-2000”, Population and Development Review, 25, 33-65.

LEE, R. (1981), "Short-term Variation: Vital Rates, Prices, and Weather", in Wrigley, E. A. and Schofield, R. S. (eds) The Population History of England 1541-1871 (Cambridge: Cambridge University Press) 356-401.

LEVY, J. S. (1983), War in the Modern Great Power System, 1495-1975 (Lexington, Kentucky: The University Press of Kentucky).

LI, B. (1998), Agricultural Development in Jiangnan, 1620-1850 (New York: St. Martin's Press).

LINDEGREN, J. (2000), "Men, Money and Means", in Contamine, P. (ed.) The Origins of the Modern State in Europe (Oxford: Oxford University Press).

LOPEZ, R. (2008), The Commercial Revolution of the Middle Ages, 950-1350 (Cambridge University Press).

LORENTZEN, P., MCMILLAN, J. and WACZIARG, R. (2008), "Death and Development", Journal of Economic Growth, 13, 81-124.

MACFARLANE, A. (1997), The Savage Wars of Peace: England, Japan and the Malthusian Trap (Oxford: Blackwell Publishing).

MADDISON, A. (2001), The World Economy. A Millennial Perspective (Paris: OECD).

MADDISON, A. (2007), Historical Statistics. University of Groningen. http://www.ggdc.net/ maddison/. 
MALTHUS, T. R. (1798), An Essay on the Principle of Population (London: Printed for J. Johnson, in St. Pauls's Church-Yard).

MALTHUS, T. R. (1826), An Essay on the Principle of Population, 6 edn (London: John Murray).

MARTIN, P., MAYER, T. and THOENIG, M. (2008), "Make Trade Not War?", Review of Economic Studies, 75, 865-900.

McEvedy, C. and Jones, R. (1978), Atlas of World Population History, Facts on File (New York). MCNEILL, W. H. (1977), Plagues and People. (New York: Anchor).

MIGUEL, E., SATYANATH, S. and SERGENTI, E. (2004), "Economic Shocks and Civil Conflict: An Instrumental Variables Approach", Journal of Political Economy, 112, 725-753.

MOKYR, J. (1990), The Lever of Riches (Oxford: Oxford University Press).

MULLETT, C. (1936), “The English Plague Scare of 1720-23”, Osiris, 2, 484-516.

MURDOCH, J. and SANDLER, T. (2002), "Economic Growth, Civil Wars, and Spatial Spillovers", Journal of Conflict Resolution, 46, 91-110.

NICOLINI, E. A. (2007), "Was Malthus Right? A VAR Analysis of Economic and Demographic Interactions in Pre-Industrial England", European Review of Economic History, 11, 99-121.

O'BRIEN, P. (1982), "European Economic Development: The Contribution of the Periphery", Economic History Review, 35, 1-18.

OSTER, E. (2009), "Routes of Infection: Exports and HIV Incidence in Sub-Saharan Africa", (University of Chicago Working Paper).

PHELPS-BROWN, H. and HOPKINS, S. V. (1981), A Perspective of Wages and Prices (London. New York, Methuen).

POMERANZ, K. (2000), The Great Divergence: China, Europe, and the Making of the Modern World Economy (Princeton, NJ: Princeton University Press).

POSTAN, M. M. (1972). The Medieval Economy and Society; an Economic History of Britain, 1100-1500. (Berkeley: University of California Press).

SALA-I-MARTIN, X., DOPPELHOFER, G. and MILLER, R. I. (2004), "Determinants of LongTerm Growth: A Bayesian Averaging of Classical Estimates (BACE) Approach", American Economic Review, 94, 813-835.

SHARP, P., STRULIK, H. and WEISDORF, J. (2012), "The Determinants of Income in a Malthusian Equilibrium”, Journal of Development Economics, 97, 112-117.

SLACK, P. (1981), "The Disappearance of the Plague: An Alternative View", Economic History Review, 34, 469-476.

SMITH, A. (1776), An Inquiry into the Nature and Causes of the Wealth of Nations. Number Smith1776 in History of Economic Thought Books. McMaster University Archive for the History of Economic Thought.

STOKEY, N. L. (2001), "A quantitative model of the British industrial revolution, 1780-1850", Carnegie-Rochester Conference Series on Public Policy, 55, 55-109.

STRULIK, H. and WEISDORF, J. (2008), "Population, Food, and Knowledge: A Simple Unified Growth Theory", Journal of Economic Growth, 13, 195-216.

SUBRAMANIAN, S. and DEATON, A. (1996), "The Demand for Food and Calories", Journal of Political Economy, 104, 133-162.

SZRETER, S. and MOONEY, G. (1998), "Urbanisation, Mortality and the Standard of Living Debate: New Estimates of the Expectation of Life at Birth in Nineteenth-Century British Cities", Economic History Review, 50, 84-112.

TALLETT, F. (1992), War and Society in Early-Modern Europe, 1495-1715 (London: Routledge). TILLY, C. (1992), Coercion, Capital, and European States, AD 990-1992 (Oxford: Blackwells). TSUI-JUNG, L. (1990), "Demographic Aspects of Urbanization in the Lower Yangzi Region of China, c. 1500-1900", in van der Woude, A. de Vries, J. and Hayami, A. (eds) Urbanization in History (Oxford: Clarendon) 328-351. 
VOIGTLÄNDER, N. and VOTH, H.-J. (2006), "Why England? Demographic Factors, Structural Change and Physical Capital Accumulation during the Industrial Revolution", Journal of Economic Growth, 11, 319-361.

VOIGTLÄNDER, N. and VOTH, H.-J. (2008), "The Three Horsemen of Growth: Plague, War and Urbanization in Early Modern Europe", (UPF manuscript).

VOIGTLÄNDER, N. and VOTH, H.-J. (2009), "Malthusian Dynamism and the Rise of Europe: Make War, not Love", American Economic Review, Papers and Proceedings, 99, 248-254.

VOIGTLÄNDER, N. and VOTH, H.-J. (2011), "How the West 'Invented' Fertility Restriction”, (NBER Working Paper 17314).

VOLLRATH, D. (2011), "The Agricultural Basis of Comparative Development", Journal of Economic Growth, 16, 343-370.

WEIL, D. (2004), Economic Growth (New York: Addison-Wesley).

WEIL, D. N. and WILDE, J. (2009), "How Relevant is Malthus for Economic Development Today?", American Economic Review, Papers and Proceedings, 99, 255-260.

WELLS, H. G. (1905), A Modern Utopia.

WOODS, R. (2003), "Urban-Rural Mortality Differentials: An Unresolved Debate”, Population and Development Review, 29, 29-46.

WRIGLEY, E. A. and SCHOFIELD, R. S. (1981), The Population History of England 1541-1871 (Cambridge: Cambridge University Press).

WRIGLEY, E. A., DAVIES, R. S., OEPPEN, J. E., AND SCHOFIELD, R. S. (1997), English Population History from Family Reconstitution 1580-1837 (New York: Cambridge University Press).

YOUNG, A. (2005), "The Gift of the Dying: The Tragedy of AIDS and the Welfare of Future African Generations", Quarterly Journal of Economics, 120, 423-466.

ZIEGLER, P. (1969), The Black Death (London: Collins). 